\title{
Bulwary nadwiślańskie na łamach prasy warszawskiej w okresie międzywojennym
}

\author{
Kamil Potrzuski | Uniwersytet Warszawski \\ Akademia Wychowania Fizycznego w Warszawie im. Józefa Piłsudskiego
}

Słowa kluczowe:

bulwary, infrastruktura, rekreacja, prasa, Warszawa, okres międzywojenny

Keywords:

boulevards, infrastructure, leisure, press, Warsaw, interwar period

\section{Streszczenie}

Warszawa w chwili odzyskania niepodległości w 1918 r. była miastem pod wieloma względami zaniedbanym. Jednym z przejawów owego zaniedbania było odsunięcie miasta od jego naturalnej osi rozwoju - Wisły, której wybrzeża zostały zabudowane obiektami przemysłowymi (gazownia, elektrownia), zabudowaniami zakładów piaskarskich i różnego typu prowizorycznymi konstrukcjami. W okresie międzywojennym prasa warszawska głośno postulowała konieczność odwrócenia miasta „frontem ku Wiśle”. Wskazywano, że powstanie reprezentacyjnego, nadbrzeżnego bulwaru wpłynie na podwyższenie poziomu bezpieczeństwa na Powiślu, stworzy ważny teren wypoczynkowy dla mieszkańców miasta, poprawi warunki komunikacyjne w Warszawie oraz podniesie jej prestiż. Niezależnie od różnic politycznych pomiędzy poszczególnymi gazetami zgadzały się one co do tego, że inwestycje nad Wisłą są konieczne. Tekst jest próbą rekonstrukcji dyskusji toczącej się na łamach prasy warszawskiej okresu międzywojennego - zarówno sportowej, jak i ogólnej na temat zagospodarowania nabrzeża Wisły w stolicy.

\section{The problem of the development of the Vistulan boulevards among press of interwar Warsaw}

\section{Abstract}

In 1918, the moment of regaining the Polish independence, Warsaw was a city neglected in many ways. One of the aspects of this neglect was its removing from the natural main axis - the Vistula river, which banks were built-up with infrastructure of less importance. In the interwar period there was an ongoing debate in the Warsaw press about the necessity of reversal the city "to face the river". It was said that creating a representational Vistulan boulevard would increase safety on coastal districts, improve urban public transport as well as make city more prestigious, making it more similar to some other Western European metropolis. Despite some political discrepancies between the editors, they all agreed that changes and investments by the Vistula are indispensable. Unfortunately, because of the outbreak of the Second World War only a little part of the Vistulan boulevards was realised. The aim of the article is to reconstruct the discussion of Vistulan banks management in the Warsaw press of the interwar years. 


\section{Wstęp}

Od powstania aż do dziś Warszawa była nierozerwalnie związana z rzeką. Wisła była dla miasta, takjak i dla całej Polski, ważnym szlakiem komunikacyjnym, handlowym, transportowym, a dla Warszawy od pewnego czasu spełniała dodatkowo funkcje rekreacyjne i wypoczynkowe'.

Rozwój stolicy w bliskim związku z Wisłą wydawał się być czymś naturalnym. Zarówno w czasach saskich, jak i stanisławowskich rzeka odgrywała niemałą rolę w rozwoju miasta². Swobodny rozwój Warszawy został jednak zaburzony, gdy w wyniku rozbiorów Rzeczpospolitej przestała być ona stolicą suwerennego kraju. Urbanistyczne i architektoniczne przemiany miasta były odtąd podporządkowane polityce zaborcy, dla którego rozwój Warszawy bynajmniej do priorytetów nie należał ${ }^{3}$ Klęska powstania listopadowego i decyzja o budowie nad brzegami rzeki Cytadeli Aleksandrowskiej, całkowicie blokującej możliwość rozbudowy stolicy w kierunku północnym, to najbardziej jaskrawy przykład sprzeczności interesów miasta i rosyjskiego zwierzchnictwa. Trzeba na marginesie dodać, że budowa Cytadeli przyczyniła się do zagłady istniejącej na jej terenach dzielnicy Joli Bord: znaczna liczba domów i zabudowań została dla potrzeb militarnych rozebrana lub zburzona, a pałacyk pijarów - letnia siedziba Collegium Nobilium, któremu Żoliborz zawdzięcza swoją nazwę - znalazł się w obrębie zabudowań Cytadeli. Przerwano też historyczną łączność Żoliborza i Nowego Miasta (Pawłowski, Zieliński 2008: 116-129). Powstanie Cytadeli było najbardziej doniosłym, choć nie jedynym aktem odpychania Warszawy od Wisły, jaki miał miejsce w ciągu całego XIX stulecia. W proces ten wpisywało się powstanie w 1856 roku na warszawskim Powiślu gazowni przy ul. Ludnej, obsługującej latarnie gazowe oświetlające miasto. Do 1888 roku (gdy powstał budynek przy obecnej ul. Kasprzaka) była ona jedyną gazownią warszawską. Zamknięta została dopiero w 1930 r. (Herbst 1975: 169). Przemysłowy krajobraz pobrzeża wiślanego w 1904 r. dopełniła elektrownia, a właściwie posiadająca własne ujęcie wody z Wisły elektrociepłownia, położona pomiędzy ulicami Tamką i Leszczyńską (Herbst 1975: 142-3) oraz związana z nią infrastruktura przemysłowa. Co ciekawe, mimo że w prasie międzywojennej obecność tego zakładu przemysłowego w sąsiedztwie rzeki raczej krytykowano, miasto nie tylko nie zmieniło lokalizacji elektrowni, ale wykonało przy niej prace modernizacyjne i rozbudowujące (w latach 1922-24 i 1937-1939). Elektrociepłownię zamknięto dopiero w latach 90. ubiegłego wieku. Pejzaż Powiśla uzupełniały liczne zabudowania mieszkalne, tworzone bez planów zagospodarowania przestrzennego czy myśli urbanistycznej, co

1 O początkach dziejów Warszawy zob. Drozdowski, Zahorski (2004: 6-29).

2 Realizacja Osi Saskiej w czasach Augusta II była jednym z pierwszych w pełni skoordynowanych działań urbanistycznych w dziejach stolicy. Szczególnie ważną rolę Wisły dla stolicy zauważył także Stanisław August, król-esteta, który planował uporządkować Powiśle - częściowo zabudowane przez domy mieszkającej tam biedoty - z myślą o stworzeniu pięknych terenów spacerowych (zob. Zahorski 1984: 296-312).

3 Szerzej zjawisko to opisuje praca Warszawa w latach 1795-1914 (Kieniewicz 1976: 47-52, 116-122, 202-207). 
pogłębiało jedynie i ugruntowało proces degradacji pobrzeża wiślanego. Wszystkie te czynniki spowodowały, że po odzyskaniu przez Polskę niepodległości w 1918 r. Warszawa była miastem niejako „odwróconym plecami” od swej największej naturalnej osi, o czym pisał Stefan Żeromski (1925: 2-3):

Istnieją miasta na podobieństwo dzieci „dobrze urodzonych”, dla których rozwoju czyniono wszystko: Rzym, Wenecja, Paryż, Wiedeń, Berlin, Petersburg. Warszawa należała do typu miast wydziedziczonych, spychanych z linii rozwoju (...). Miasto rosło samopas (...).W ogromnych rozłogach nad Wisłą, gdzie było powietrze dla podrastających pokoleń i miejsce pod najzdrowsze, nowoczesne dzielnice, powstały pustki albo zaczęły wyrzucać kłęby dymu fabryczne kominy. (...)W takim położeniu rzeczy zastała je wieść od tylu pokoleń upragniona - wolność. Przygotowują się architekci, inżynierowie i artyści, ażeby wielkie, zaniedbane, bezładne miasto opasać nieprzerwaną linią ogrodów, wychodzącą ze zburzonej i zadrzewionej Cytadeli, wzdłuż Wisły, i po drugiej stronie nieszczęsnych dzielnic ${ }^{4}$.

Nie był to pierwszy ani jedyny głos w debacie publicznej, dotyczący zagospodarowania brzegów Wisły w Warszawie. Próbę rekonstrukcji tej debaty zamierzam podjąć w niniejszej pracy. Wykorzystam do tego celu prasę warszawską. Pod pojęciem tym rozumiem wydawnictwa ciągłe (gazety oraz czasopisma) redagowane i wydawane w Warszawie (choć bynajmniej nieograniczające się do tematyki lokalnej). W pracy pojawią się przede wszystkim odwołania do tytułów wysokonakładowych, poczytnych $\mathrm{i}$ istotnych jako czynniki opiniotwórcze o ogólnopolskim zasięgu. Prasa ta, jak się wydaje, w znacznym stopniu kreowała opinie mieszkańców stolicy (i nie tylko) dotyczące zagospodarowania brzegów Wisły. Jej lektura pozwala wysnuć przypuszczenia dotyczące tego, w jakich aspektach słabość zagospodarowania Wisły mogła być dla mieszkańców stolicy szczególnie uciążliwa. Dla porządku należy zaznaczyć, że przedmiotem badań była prasa popularna, nie odwoływałem się zaś do prasy specjalistycznej (np. „Architektura i Budownictwo”, „Przegląd Budowlany” itp.).

Zgodnie z ustaleniami twórców Bibliografii Warszawy (Durko 1977: 665; Durko 1984: 725-726), na łamach prasy stołecznej w latach 1920-1939 ukazało się łącznie 56 artykułów dotyczących bezpośrednio bulwarów nadwiślańskich ${ }^{5}$. Najwięcej publikował na ten temat „Kurier Warszawski"6, w którym w latach 1925-1936 ukazało się 16 artykułów dotyczących kwestii Wisły w Warszawie. Problem budził też żywotne zainteresowanie

\footnotetext{
${ }^{4}$ Wszystkie fragmenty artykułów prasowych przytaczam w ich oryginalnym brzmieniu. Fragmenty pominięte zostały zaznaczone. W niektórych przypadkach zastosowałem uwspółcześnienie pisowni zgodnie z obowiązującą do dziś reformą ortografii polskiej z $1936 \mathrm{r}$.

5 Udało mi się dotrzeć do 48 z nich, tj. 85\%. W przypadku kilku artykułów zachodzi podejrzenie, że pojawiły się one w Bibliografii Warszawy pod hasłem „bulwary nadwiślańskie” omyłkowo. Mam tu na myśli choćby odnośniki do kolumn sportowych „Gazety Polskiej” z 1936 r. (nr 158 i 262). Pozycje te znalazły się w rzeczonym rozdziale Bibliografii Warszawy, choć po ich przejrzeniu można stwierdzić, że nie zawierają żadnych informacji na temat Wisły w Warszawie. Z powodu braku kompletności materiału źródłowego wnioski stawiane w pracy obarczone są pewnym ryzykiem popełnienia błędu. 6 „Kurier Warszawski” ukazywał się od 1822 r. W okresie międzywojennym był już pismem o wysokim nakładzie (wg różnych źródeł od 50 do nawet 100 tys. egzemplarzy) i znacznym zasięgu. Wychodził codziennie, dwukrotnie - wydanie poranne liczyło 6 kolumn, wieczorne (a właściwie popołudniowe) 16, w niedzielę ukazywał się tylko raz. Choć formalnie apolityczny i niezwiązany bezpośrednio
} 
takich dzienników, jak „Gazeta Polska"7 (osiem tekstów) , Gazeta Warszawska"8 (cztery artykuły), "Robotnik"9 (dwa teksty) „Rzeczpospolita”10 (dwa teksty) czy „Polska Zbrojna"11 (sześć artykułów), a zatem gazet o bardzo różnej orientacji politycznej i światopoglądowej. W przypadku czasopism najwięcej zainteresowania Wisłą, ze zrozumiałych względów, wykazywała „Kronika Warszawy"12 (cztery artykuły), choć tematyka ta pojawiała się także na łamach innych periodyków, jak choćby „Świat"13.

Problematyka bulwarów nadwiślańskich była najsilniej obecna na łamach prasy warszawskiej w latach 1925-1928, a zwłaszcza w 1935-1936, gdy powstało odpowiednio

z żadną partią polityczną (tak jak jego redaktor naczelny od 1924 r., Konrad Olchowicz), uchodził za prawicowy, zbliżony do narodowej demokracji oraz ZLN (por. Paczkowski 1980: 47-49).

7 "Gazeta Polska" powstała w 1929 r. z inicjatywy płk. Adama Koca z tzw. grupy pułkowników obozu piłsudczykowskiego. Pozostawała do końca okresu międzywojennego prorządowym, sanacyjnym pismem (po śmierci Piłsudskiego i dekompozycji obozu rządowego związana z grupą GISZ). Na forum międzynarodowym tezy zawarte w jej artykułach utożsamiano, często nie bez racji, ze stanowiskiem rządu polskiego. Od 1937 r. uznana organem naczelnym OZN, założonego przez A. Koca. Jej nakład wynosił ok. 30 tys. egzemplarzy, a tematyka ogniskowała się głównie wokół spraw politycznych (por. Paczkowski 1980: 146-147).

8 "Robotnik", gazeta silnie lewicująca, socjalistyczna, centralny organ PPS. Powstała w 1894 r., ale dopiero od 1918 r. ukazywała się legalnie. Nie była pismem wielkonakładowym - w okresie międzywojennym nakład nie przekraczał kilkunastu tys. egzemplarzy (w 1919 r. 8-10 tys.). Po zamachu majowym „Robotnik" musiał liczyć się z nieprzychylnym stosunkiem władz, ukazywał się jednak regularnie aż do wybuchu wojny. Jego wieloletni redaktor naczelny Mieczysław Niedziałkowski został rozstrzelany w Palmirach pod Warszawą w 1940 r. W tym czasopiśmie kwestia bulwarów nadwiślańskich wzbudzała umiarkowane zainteresowanie (por. Paczkowski 1980: 72-74).

9 "Gazeta Warszawska" wychodziła od 1918 r. Była organem naczelnym ZLN, pismem silnie prawicowym, endeckim. Jej nakład osiągał do 25 tys. egzemplarzy (w 1930 r.), wbrew nazwie w dużej mierze kolportowana była poza Warszawą. W latach 1935-1939 ukazywała się jako„Warszawski Dziennik Narodowy", pod tym tytułem nie pisała już o bulwarach nadwiślańskich (por. Paczkowski 1980: 31, 144).

${ }_{10}$ „Rzeczpospolita" powstała w czerwcu 1920 r. Jej ojcem opatrznościowym był Ignacy J. Paderewski, do 1924 r. hojnie wspierającym ją finansowo i posiadającym większościowy pakiet akcji (ich sprzedaż Wojciechowi Korfantemu stała się zresztą przyczynkiem do jednego z pierwszych skandali prasowych w Polsce). Była organem prasowym SChN o orientacji prawicowej, chadeckiej. Nie imponowała wysokim nakładem - z reguły nie przekraczał on 20 tys. Podobnie jak w przypadku „Robotnika”, bulwary nadwiślańskie leżały zdecydowanie na marginesie jej zainteresowań (por. Paczkowski 1980: 41-43).

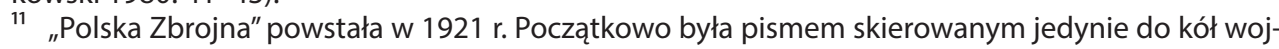
skowych, z biegiem czasu stała się gazetą ogólnoinformacyjną, jedynie szerzej niż inne dzienniki poruszającą problematykę militarną. Ze względu na związki z Ministerstwem Spraw Wojskowych i Generalnym Inspektoratem Sił Zbrojnych pozostawała aż do 1939 r. silnie prorządowa. W okresie międzywojennym jej nakład wahał się od 6 do 10 tys. egzemplarzy, co sugeruje, że nie udało jej się wyjść poza krąg czytelników wojskowych (por. Paczkowski 1980: 106-107).

${ }_{12}$ „Kronika Warszawy” była miesięcznikiem wydawanym od 1925 do 1939 r. przez magistrat m. st. Warszawy, poświęconym działalności samorządu miejskiego, historii Warszawy i jej bieżącym problemom. Nakład wynosił od 1 tys. egz. (1925 r.) do 3 tys. egz. (1932 r.). Po wojnie, od 1970, ukazuje się pod tym samym tytułem kwartalnik popularnonaukowy wydawany przez PWN (por. Herbst 1975: 310).

${ }^{13}$ "Świat", tygodnik wydawany w Warszawie przez cały omawiany okres, był czasopismem poruszającym aktualne zagadnienia z zakresu kultury, życia artystycznego kraju i zagranicy, spraw społecznych, a także politycznych. Jego nakład wahał się miedzy 12-15 tys. egzemplarzy, miał jednak grono stałych czytelników, głównie wśród szeroko pojętej inteligencji. W 1930 r. opublikował jedyny, acz bardzo cenny materiał, dotyczący Wisły w stolicy - wywiad z inż. Henrykiem Orleańskim (por. Paczkowski 1980: 278-279). 
11 i 20 artykułów poświęconych tej tematyce. Wydaje się to zrozumiałe ze względu na okres prosperity, jaki przeżywała Polska w drugiej połowie lat 20. Wiele projektów inwestycyjnych doczekało się wówczas finalizacji - wymieńmy choćby rozbudowę wodociągów i kanalizacji, sieci tramwajowej (48 kilometrów nowych tras), gazowniczej, budowę nowych mieszkań (24,3 tys.), czy wreszcie realizację i oddanie do użytku kompleksu Centralnego Instytutu Wychowania Fizycznego na Bielanach w 1929 r. (Gawkowski 2007: 310). Istniały zatem podstawy, by z optymizmem, głośno i odważnie wspominać o modernizacji nadrzecznych arterii. Entuzjazm ze zrozumiałych względów przygasł w pierwszej połowie lat 30. Choć w okresie wielkiego kryzysu nie pisano tak wiele o zagospodarowaniu Wisły, to stwierdzenie, że temat ten zniknął wówczas zupełnie z kręgu zainteresowań dziennikarzy, byłoby nadużyciem. W latach 1929-1933 ukazało się w interesujących nas gazetach 15 pozycji traktujących o zagospodarowaniu brzegów Wisły, skądinąd bardzo cennych, ponieważ uwypuklały niektóre problemy, mniej widoczne w czasie koniunktury. Przykładowo w artykule Wisła i wybrzeża "Kurier Warszawski" donosił:

Warszawa musi podczas tego lata specjalnie przygotować się na pobyt w mieście rzesz mieszkańców, którzy normalnie, rokrocznie wyjeżdżali na letniska i do uzdrowisk. W roku bieżącym będzie inaczej - miasto nie wyludni się tak bardzo, jak zazwyczaj w miesiącach letnich. Stolica nie może zaniedbywać pierwszorzędnych walorów przyrodzonych. (...) Byłoby dobrze, aby lato bieżące pchnęło sprawę na nowe tory, aby (...) Wisła i jej brzegi mogły służyć Warszawie sprawnie i przystępnie(„Kurier Warszawski” 1932: 10-11).

W czasach kryzysu, gdy liczba mieszkańców wyjeżdżających z Warszawy na wakacje zmniejszyła się, wyraźniej ujawnił się problem braku terenów zielonych i wypoczynkowych w stolicy.

W okresie kolejnej koniunktury $i$ "odrabiania strat" temat z jeszcze większą regularnością pojawiał się na łamach prasy. Ogromne znaczenie dla wzrostu zainteresowania zagadnieniem bulwarów nadwiślańskich w połowie lat 30. miało rozpoczęcie prac przygotowujących do użytku odcinek bulwarów od mostu Kierbedzia do Cytadeli (ich zakończenie planowano na początek lat 40.).W 1935 r. w tym rejonie przy ul. Wybrzeże Gdańskie, około sto metrów na północ od dzisiejszego mostu Śląsko-Dąbrowskiego, wmurowano tablicę okolicznościową. Napis na niej brzmi:

W roku żałoby narodowej z powodu zgonu wielkiego marszałka Józefa Piłsudskiego, gdy prezydentem Rzeczypospolitej był prof. dr Ignacy Mościcki, generalnym inspektorem sił zbrojnych gen. Edward Śmigły-Rydz, prezesem Rady Ministrów Walery Sławek, ministrem spraw wewnętrznych Marian Zyndram-Kościałkowski, prezydentem miasta Stefan Starzyński, wiceprezydentem działu budownictwa Jan Pohoski, rozpoczęto wznoszenie kamiennych bulwarów nad Wisłą oraz budowę Wybrzeży Gdyńskiego i Gdańskiego (...). Pracę rozpoczęto w sierpniu 1935 r. przed Zamkiem Królewskim przy moście Kierbedzia, (...) odcinek do mostu przy Cytadeli ukończono w roku 194... 
Spośród wszystkich międzywojennych artykułów dotyczących bulwarów nadwiślańskich daje się wyodrębnić dwie podstawowe grupy tekstów: relacyjne (lub też sprawozdawcze $)^{14}$ oraz wizjonerskie. Bardziej interesować nas będzie ten drugi rodzaj, dający obraz tego, jaki wygląd bulwarów nadwiślańskich postulowano oraz jak mogły one w powszechnej świadomości wyglądać w perspektywie przyszłych kilkunastu lat.

Tematyka budowy bulwarów nadwiślańskich, a w szczególności odbicia tej inicjatywy budowlanej w prasie, jest zaskakująco słabo opracowana w literaturze przedmiotu. Bardzo pobieżnie sprawy związane z Wisłą opisuje w ciągle najpopularniejszej syntezie dziejów Warszawy omawianego okresu Marian M. Drozdowski (1991). Również w obszernym zbiorze jego artykułów monograficznych zatytułowanym Warszawa II Rzeczpospolitej (1968, 1970, 1971, 1972, 1973) ani jeden tekst naukowy nie traktuje bezpośrednio o rekreacyjnym, turystycznym czy komunikacyjnym wykorzystaniu wybrzeży Wisły. Cenne skądinąd opracowania dotyczące architektury i urbanistyki Warszawy pochodzące z czasów międzywojennych i tuż po Il wojnie światowej ${ }^{15}$ muszą być traktowane bardziej jako źródła niż opracowania dla badanego zagadnienia. Na podstawie istniejącej literatury przedmiotu trudno wręcz odtworzyć z zachowaniem chronologicznej dokładności przebieg wszystkich prac na pobrzeżu Wisły (zwłaszcza tych związanych z budową bulwarów) w okresie międzywojennym. Artykuł niniejszy ma szansę stać się przyczynkiem do opracowania dziejów wykorzystania Wisły w Warszawie międzywojennej, problematyka wymaga jednak z pewnością dalszych badań.

Pierwsza wzmianka dotycząca Wisły i jej bezpośredniego otoczenia w obrębie Warszawy ukazała się w $1920 \mathrm{r}^{16}$, tematyka ta w prasie stołecznej zadomowiła się jednak dopiero w pięć lat później. Może zaskakiwać, dlaczego ważny aspekt rozwoju stolicy pozostawał nieobecny na łamach gazet aż do tego czasu. Do pewnego stopnia można wyjaśnić to tym, że w pierwszych latach niepodległości Polska przeżywała problemy ważniejsze i bardziej rozpalające opinię publiczną (mam tu na myśli walki o granice kraju, pierwsze - odbywające się w atmosferze skandalu - wybory parlamentarne i prezydenckie oraz inne problemy polityki wewnętrznej). Dopuszczalna i bardziej przekonująca wydaje się jednak hipoteza, że w pierwszych latach niepodległości sprawą kluczową dla rozwoju stolicy nie była regulacja i zagospodarowanie Wisły, ale raczej zintegrowanie miasta z nowymi dzielnicami, wchodzącymi w obręb Warszawy od momentu tzw. wielkiej inkorporacji z 1916 r., kiedy to decyzją administracji niemieckiej doszło do blisko trzykrotnego zwiększenia powierzchni miasta poprzez przyłączenie terenów pozostających poza obrębem pierścienia fortów rosyjskiej twierdzy.

\footnotetext{
14 W artykułach relacyjnych nierzadko z wykorzystaniem fachowej, technicznej terminologii, zdawano przede wszystkim relacje z prac prowadzonych nad brzegami rzeki, natomiast w wizjonerskich przedstawiano wizję wyglądu i wykorzystania rzeki w Warszawie za kilka czy kilkanaście lat. 15 Takimi pracami były choćby Klein, Rudnicki (1928), Szwankowski (1952), Gniewiński (1939).

${ }^{16}$ Chodzi o krótką notkę informacyjną głoszącą: „dla uczczenia i upamiętnienia doniosłego faktu objęcia z powrotem przez Polskę części polskiego wybrzeża na Pomorzu, Rada m. st. Warszawy uchwaliła [...] nadać bulwarowi na lewym brzegu Wisły od mostu Kierbedzia do mostu kolejowego nazwę Wybrzeże Gdańskie" zamieszczoną w: (Dzienniku Zarządu Miejskiego (1920: 1).
} 
Rozszerzenie to dawało Warszawie już po odzyskaniu niepodległości nowe perspektywy rozwoju, jednak wymagało podjęcia intensywnej akcji budowlanej (np. na niezamieszkałych terenach za Cytadelą, na Żoliborzu ${ }^{17}$ ) i połączenia komunikacyjnego ze stolicą (Drozdowski 1991: 78-83.). Obie te hipotezy wymagają weryfikacji poprzez bardziej wnikliwe badania źródłowe. Z pewnością nie bez znaczenia pozostawało to, że prasa bardziej zainteresowała się kwestią zagospodarowania i użyteczności Wisły w Warszawie, gdy w 1925 r. oddano do użytku pierwszą część bulwaru nadrzecznego.

Pierwszy etap prac na pobrzeżu Wisły prowadzono w centralnej części miasta na Wybrzeżu Kościuszkowskim, obszarze pomiędzy mostem Poniatowskiego a nieistniejącym już dziś mostem Kierbedzia ${ }^{18}$. Podczas końcowego etapu robót, w marcu 1925 r. „Kurier Warszawski” opublikował felieton Od mostu Kierbedzia do mostu kolejowego, w którym autor, redaktor Adam Wolmar ${ }^{19}$, poruszał kilka ciekawych zagadnień:

Dużo już pisano i mówiono o całkowitym zaniedbaniu pobrzeża Wisły, o sprzeniewierzeniu się tej naturalnej ozdobie i krasie miasta. Ale zło nie jest tak beznadziejne, aby nie dało się naprawić. Na przestrzeni od mostu Kierbedzia do mostu Poniatowskiego zrobiono już coś niecoś. (...) Most Kierbedzia dzieli brzeg jakby na dwie części, sylwety nadbrzeżne tych części różnią się widocznie. W kierunku Bielan oszpecona doszczętnie, pozostawiona dotąd psom bezdomnym, kozom i ptakom niebieskim - poczyna z wolna budzić się, iść śladami pierwszej. Tu zdają się być nagromadzone brudy całego miasta. Przecinająca ul. Sternkele$\mathrm{ra}^{20}$ daje początek bezmyślnie i bezplanowo rozwalającym się przy brzegu budynkom. (...) Tu też praca idzie żwawo. (...) Obecnie miasto urządza tamę, która będzie zasypana ziemią. Wisła zwęzi tu koryto. Już najwyższy czas, aby regulacja Wisły przyjęła kształty realne. Te krańce miasta niebawem stać się mogą Śródmieściem, a wtedy brzeg Wisły nie może być taki marny, pusty i nijaki. Bulwary w znaczeniu zachodnioeuropejskim są melodią przyszłości. Ale cokolwiek tu stanie, ma (...) stać się naprawdę ozdobą. Nie brudzić i nie psuć (1925: 16-17).

W tym pierwszym dużym tekście dotyczącym bulwarów nadwiślańskich, jaki ukazał się na łamach międzywojennej wysokonakładowej prasy warszawskiej, pojawia się od razu kilka problemów, które przewijać się będą na łamach prasy w całym omawianym okresie: znaczenie uporządkowania brzegów Wisły dla bezpieczeństwa w tej części miasta, wielki potencjał komunikacyjny i wypoczynkowo-spacerowy przyszłych terenów nadrzecznych czy wreszcie kwestia zasypania przepaści, dzielącej pod względem urbanistycznym Warszawę od miast Europy Zachodniej.

17 Powstawały tu nowoczesne, spółdzielcze osiedla zarówno domów jednorodzinnych o charakterze willowym, zamieszkiwane przez oficerów, administrację państwową czy dziennikarzy, jak też grupy większych kamienic budowanych przez Warszawską Spółdzielnię Mieszkaniową (WSM) pierwotnie z myślą o robotnikach. $O$ akcji budowlanej w tej dzielnicy traktuje obszerny fragment cytowanego już przewodnika historycznego po Żoliborzu (Pawłowski, Zieliński 2008: 160-212).

${ }_{18}$ Most był odpowiednikiem współczesnego mostu Śląsko-Dąbrowskiego.

19 Adam Wolmar był znanym varsavianistą, publicystą „Kuriera Warszawskiego", piszącym o aktualnych problemach stolicy - zarówno brakach w infrastrukturze, jak i podejmowanych inwestycjach. W jego tekstach pojawiały się najśmielsze wizje bulwarów nadwiślańskich przyszłej Warszawy.

20 Tak w oryginale - chodzi tu w rzeczywistości o warszawskiego przedsiębiorcę, Piotra Steinkellera, znanego przede wszystkim z uruchomienia w 1838 r. kursów dyliżansowych łączących Warszawę $z$ innymi dużymi miastami. 
Kilometrowy fragment nabrzeża pomiędzy mostem Kierbedzia a mostem Poniatowskiego ukończono latem 1925 r., a jako pierwszy poinformował o tym „Robotnik” (1925: 4):

Bulwary między mostem Kierbedzia a mostem ks. Poniatowskiego są już zupełnie wykończone. Na górnym bulwarze urządzono plantację oraz dwie jezdnie z chodnikami. Przez dolny bulwar przebiega linia kolei państwowej obsługująca brzeg Wisły pod względem ruchu towarowego. Bulwary oświetlone są obecnie gazem i elektrycznością. Wkrótce jezdnia z kamienia polnego zastąpiona zostanie kostką granitową. Wydział techniczny magistratu opracowuje projekt wykonania bulwaru od mostu ks. Poniatowskiego do ul. Solec, i po zasypaniu brzegu Wisły, do podłużnej tamy biegnącej od mostu Kierbedzia w stronę Bielan, przystąpi do urządzenia bulwaru na tym odcinku, co wytworzy łącznie z parkiem Traugutta piękną całość.

„Gazeta Warszawska” (1925: 3) pisała o tym wydarzeniu w następujący sposób:

Brzegi Wisły między mostem ks. Poniatowskiego i mostem Kierbedzia nareszcie nabrały europejskiego wyglądu. Na całej przestrzeni wykończono budowę bulwarów i zjazdów z górnego bulwaru na dolny. Bulwary otrzymały oświetlenie elektryczne i gazowe. Magistrat projektuje wykonanie nowego bulwaru od mostu ks. Poniatowskiego do ul. Solec, dotychczas dzielnica ta nie miała nic wspólnego z Europą, posiada zaś wszelkie dane, ażeby stać się jednym z najpiękniejszych miejsc spacerowych w stolicy.

Co znamienne, komentarz w obu tych gazetach jest niezwykle podobny, jak widać zatem, budowa bulwarów nad Wisłą nie budziła skrajnych emocji i w większości periodyków była komentowana w sposób w dużej mierze niezależny od orientacji politycznej. Liczba zamieszczanych tekstów dotycząca tego zagadnienia była wprawdzie zróżnicowana, jednak postawienie tezy o jakiejkolwiek zależności pomiędzy politycznymi sympatiami gazety a jej nastawieniem do spraw Warszawy i Wisły byłoby trudne i, moim zdaniem, nieuprawnione.

W 1928 r. prasa zaczęła pisać o konieczności uporządkowania dalszych części pobrzeża, zatem w „Gazecie Warszawskiej” (1928: 2) można było przeczytać:

Wydział techniczny magistratu przystąpił do prac zmierzających do przekształcenia wybrzeża Kościuszkowskiego na miejsce spacerowe dla mieszkańców stolicy na wzór bulwarów w miastach europejskich. Na ułożenie jezdni i chodników wzdłuż całego wybrzeża i inne prace nad uporządkowaniem ulic przyległych do wybrzeża przeznaczonych ma być 1140000 złotych,

zaś „Polska Zbrojna” (1928: 6) z pierwszych dni grudnia tegoż roku donosiła:

Przystąpiono do uporządkowania lewego brzegu Wisły od mostu Kierbedzia do ul. Boleść. Wbijana jest ścianka szpandalowa długości 510 m. Po ukończeniu tych robót wydział techniczny magistratu przystąpi do oskarpowania brzegu, po czym ustawione będą latarnie elektryczne i powstały w ten sposób bulwar będzie oddany do użytku. Nastąpić to ma do końca maja 1929 r. Bulwar ten o szerokości od 60 do 65 m, będzie sąsiadował bezpośrednio z ogrodem Zamku Królewskiego. 
Szczególną uwagę należy zwrócić na pojawienie się w tekście kwestii sąsiedztwa bulwarów z ogrodami Zamku Królewskiego. Wykorzystanie widoku zamku z bulwarów do nadania miastu powagi było wielokrotnie poruszane. Zaznaczmy, że w XVIII w. Zamek Królewski był dobrze widoczny z pobrzeża wiślanego. Wyeksponowany szczególnie dzięki odpowiedniej odległości i perspektywie z praskiego brzegu (co widać chociażby na obrazach (analetta ${ }^{21}$ ), w dobie rozbiorów został zaniedbany, a przez nieskoordynowaną zabudowę doszło do jego zasłonięcia tak, że stał się niewidoczny znad brzegów Wisły. Stefan Kieniewicz pisze o roli Zamku Królewskiego w rozbiorowej Polsce w następujący sposób: „Warszawa nie była już stolicą i nie potrzebowała monumentalności. Inżynier G. Kori w latach 1851-1852 przebudował fasadę Zamku, obniżając dach i zasłaniając go banalną attyką. "Gmach zapadł się niejako w stosunku do Starego Miasta»" (Kieniewicz 1976: 121). W prasie międzywojennej pojawiały się głosy, że w stolicy niepodległego już państwa sytuacja taka jest wysoce nieodpowiednia, wręcz patologiczna i zamek musi być jak najszybciej odsłonięty, aby ponownie stać się ozdobą miasta. Nie bez znaczenia był tu aspekt prestiżowy. Pisano, że ekspozycja zamku symbolicznie przypomni o dawnej stołeczności miasta i ukaże, że Warszawa nie jest miastem prowincjonalnym, wyniesionym do rangi stolicy, ale jedynie odzyskała należny jej status:

Krzywda, jaka stała się Wiśle w Warszawie, zaczyna być stopniowo naprawiana. Właściwe wyzyskanie wybrzeży, pięknych bulwarów nawiedzanych ożywionym gwarem spacerowym, może dopiero nastąpić wówczas, gdy Wisła będzie uregulowana. A jest to sprawa niełatwa i nietania. (...) Niemniej brzegi muszą być uporządkowane. (...) Dalekie to jeszcze czasy, gdy bulwary warszawskie zastąpią rolę dzisiejszych Alei Ujazdowskich, ale miasto opamiętało się. Brzegom Wisły przywraca się należne im stanowisko. Przywraca - bo za czasów stołecznych zawsze należały do miejsc uprzywilejowanych. Tu (...) dźwignięto Zamek Królewski, któremu dano pyszne ramy tarasowe (...) Zamek Królewski budzi się z letargu, w jaki zapadł po upadku Rzeczpospolitej. Będą mu przywrócone cechy monumentalne, jakie posiadał. Granicami sięgać będzie Wisły. Za czasów rosyjskich, kiedy Zamek był ogrodzony budynkami koszarowymi, kiedy ginął w chaosie gęsto rosnących drzew - odcinek wybrzeża nie stanowił żadnego monumentu architektonicznego. Zwyczajnie przepadał („Kurier Warszawski” 1928: 17).

Nawiasem mówiąc warto dodać, że odsłonięcie Zamku Królewskiego było tylko jednym z działań derusyfikacyjnych, jakie w pierwszych latach niepodległości starał się prowadzić magistrat. W tym samym celu w latach 20. dokonano gruntownej przebudowy Pałacu Staszica na Krakowskim Przedmieściu, usuwając jego bizantyjsko-ruski kostium, czy też rozebrano sobór św. Aleksandra Newskiego na placu Saskim (obecnie plac Piłsudskiego).

Cytowany powyżej tekst to niejedyny przykład śmiałej wizji restauracji brzegów Wisły w granicach Warszawy i nadania im roli reprezentacyjnej, jaki zamieszczono na łamach

${ }^{21}$ Chodzi tu zwłaszcza o obrazy Canaletta Widok Warszawy od strony Pragi z 1770 r. i Widok Warszawy od Pałacu Ostrogskich do Zamku Królewskiego z 1774 r. (por. Canaletto 1770, 1774). 
„Kuriera Warszawskiego". Czasopismo to w najodważniejszy sposób prezentowało wyobrażenie bulwarów w niedalekiej przyszłości:

Wisła stopniowo zaczyna cieszyć się uznaniem w Warszawie. (...) Wielkie bulwary... Stają przed oczyma wspaniałe arterie, szerokie, gładkie, lśniące, równe, rzędami drzew wysadzone. Paraduje po nich wielki świat. Oślepiające światła rozsnuwają czary efektów. Płyną z nich urocze tony muzyki. Z wysokich tarasów podziwiać można symfonię kolorową nieba i wody" („Kurier Warszawski" 1930: 5-6).

Tendencja ta utrzymywała się w początkach lat 30::

Od kilku lat poczęto w Warszawie interesować się Wisłą. Bulwary nad nią nie są już przedmiotem drwin i kpin. Przestają być punktem zbornym szumowin, ptaków błękitnych, apaszów nadwiślańskich i innych mętów. Wybrzeże Kościuszkowskie ma już śród trawników, skwerów i kwietników pierwszy pomnik (Dowborczyka). Staje się miejscem spacerów i wypoczynku. Miejscem coraz mniej niebezpiecznym. (...) Chcielibyśmy zwrócić uwagę na bulwar, ciągnący się w dół rzeki ku staremu mostowi kolejowemu [tj. most Gdański - przyp. K.P.]. Na tym odcinku roztacza się najpiękniejsza panorama starej Warszawy, rozciągającej się malowniczo na wzgórzach. Przy tym wybrzeżu roztacza się Zamek Królewski. (...) Bulwar u stóp zamku powinien rozciągać się pasem możliwym do Żoliborza i dalej poza Bielany i Młociny. (...) Bulwar pod Zamkiem, o ważnym znaczeniu spacerowym, winien być urządzony tak, aby mógł służyć również do jazdy samochodowej. Piękna i wygodna trasa prowadziłaby najwłaściwiej do Żoliborza („Kurier Warszawski" 1931: 5).

Znamienne jest to, że odważne wizje rozwoju nadwiślańskich bulwarów snuto nawet w latach głębokiego kryzysu gospodarczego, gdy wydatki inwestycyjne miasta dramatycznie spadły (w latach 1926/27 do 1929/30 miasto wydało na inwestycje 208,1 mln zł, a w kryzysowym okresie 1930/31 do 1933/1934 tylko 96,8 mln zł, tak więc o blisko $60 \%$ mniej; w kolejnych latach suma ta ponownie wzrosła - w latach od 1934/1935 do 1937/1938 (a więc w trzy-, a nie czteroletnim okresie) wydano 121,4 mln zł (Starzyński 1938: 77). Wydaje się to szczególnie ciekawe, jeśli przypomnimy sobie, że już w połowie lat 20. gazety różnych opcji otwarcie pisały, że regulacja Wisły oraz uporządkowanie i adaptacja bulwarów nadrzecznych będzie inwestycją bardzo kosztowną. Nigdzie jednak nie pojawiły się głosy, że należałoby zaniechać budowy bulwarów ${ }^{22}$. Warto byłoby wnikliwiej zastanowić się, dlaczego sens inwestycji w uporządkowanie brzegów Wisły nie był nigdy podważany na łamach prasy i żaden magistrat nie spotkał się z tytułu wydawania pieniędzy na ten cel z cieniem krytyki, a jeśli taka miała miejsce, to raczej ze względu na zbyt mało energiczne realizowanie projektu bulwarów. Przykładowo w 1930 r. "Rzeczpospolita” w artykule o wymownym tytule i podtytule Nasze bulwary. Bolaqczki Warszawy (1930b: 8) niezbyt łaskawie recenzowała działania prezydenta miasta Zygmunta Słomińskiego ze względu na jego nie dość energiczne dążenie do uruchomienia budowy odcinka bulwarów nadwiślańskich Zamek-Bielany.

22 Nawet w czasie pogłębiającej się recesji pisano o potrzebie prowadzenia doraźnych prac nad Wisłą i przyspieszenia robót po okresie wyjścia z kryzysu. 
Świadczy to, jak się zdaje, że bulwary nadwiślańskie uważano za coś absolutnie niezbędnego Warszawie.

Dlaczego jednak w oczach międzywojennych dziennikarzy były one czymś aż tak ważnym? Odpowiedzi na to pytanie można szukać w wielu czynnikach i zjawiskach charakterystycznych dla Warszawy okresu dwudziestolecia międzywojennego. Jednym z nich był niewątpliwie deficyt terenów wypoczynkowych, rekreacyjnych i zieleni miejskiej w ówczesnej stolicy oraz pozytywna rola, jaką mogłyby odegrać bulwary dla poprawy jakości życia jej mieszkańców. Kolejne magistraty starały się rozwiązać problem braku terenów zielonych i wypoczynkowych:

W planie regionalnym wielkiej Warszawy zieleń potraktowana jest względnie bardzo dobrze. W projekcie przewidziane jest powstanie szeregu nowych parków, które, wraz z obecnie istniejącymi, zajmą powierzchnię 2.536 ha. (...) Otrzymamy $15 \mathrm{~m}^{2}$ [zieleni na mieszkańca przyp. K.P.], a więc ilość zbliżoną do norm Wagnera $\left(19,5 \mathrm{~m}^{2}\right)$

- pisał Stefan Starzyński (Warszawa przyszłości 1936: 98). Powstanie bulwarów nadwiślańskich wiązałoby się również naturalnie ze zwiększeniem obszarów rekreacyjnych, w tym kontekście stając się przedsięwzięciem ważnym dla zrównoważonego rozwoju miasta:

Wprawdzie nie wolno pominąć milczeniem olbrzymiego postępu w dziedzinie bruków, oświetlenia, komunikacji i architektury (...), wszystko to jednak nie dało mieszkańcom stolicy tego, czego brak dotkliwy daje się odczuć zwłaszcza latem - odpowiednich miejsc dla spaceru, wypoczynku i wytchnienia. (...) W Warszawie brak terenu, który łączyłby wygodę z malowniczością położenia, był obszerny i łatwo dostępny dla mieszkańców przynajmniej kilku dzielnic miasta

- pisała „Rzeczpospolita” (1930b: 8).

Kolejną, być może najważniejszą przyczyną, dla której zdawano sobie sprawę z niezbędności inwestycji, była możliwość wykorzystania górnego bulwaru jako arterii komunikacyjnej, łączącej Śródmieście z rozwijającymi się dzielnicami północnymi, zwłaszcza Żoliborzem. Szczególnie ważne stawało się to w kontekście bardzo słabego połączenia i utrudnionego dojazdu z dynamicznie rozwijających się dzielnic do centrum miasta. Do czasu budowy wiaduktu nad torami kolei obwodowej, ostatecznie otwartego w 1937 r. i przebicia ul. Bonifraterskiej, nie istniało niemal wygodne połączenie Żoliborza ze Śródmieściem. Wąski, zalewany okresowo przez wodę deszczową tunel na dzisiejszej ul. Krajewskiego stanowczo nie odpowiadał na zapotrzebowanie. Wszystko to tylko pogłębiało konieczność budowy Wisłostrady, położonej na nadbrzeżnym bulwarze (Pawłowski, Zieliński 2008: 242-246). Nie bez znaczenia był też fakt, że bardzo zatłoczone i zakorkowane ulice Śródmieścia, jak choćby Nowy Świat, wymagały odciążenia. O komunikacyjnym wykorzystaniu terenów nad Wisłą wspominano w prasie niejednokrotnie:„Nie tylko względy reprezentacyjne i estetyczne przemawiają za uporządkowaniem wybrzeża pod Zamkiem, ale również bardzo 
utylitarne: jeszcze jedno, najkrótsze, najprostsze, a do tego najładniejsze połączenie z Żoliborzem” („Kurier Warszawski” 1931: 5). Niecałe dwa lata później, w roku 1933 pisano: „W przyszłości droga Wilanów - Bielany odbywać się może wzdłuż brzegów Wisły. Wybrzeże przejmie część ruchu z Nowego Światu i Krakowskiego Przedmieścia” („Kurier Warszawski" 1933: 14). Kolejne dwa artykuły z 1936 r. zwracały uwagę na ten problem: „Wybrzeże Gdańskie otrzyma gładką nawierzchnię aż do Cytadeli. Musi koniecznie powstać (najrychlej!) nowa, nadbrzeżna arteria. Od lat wytykamy nieprawdopodobną okoliczność jedynego przejazdu do siedziby kilkudziesięciu tysięcy stałej ludności przez wąską paszczę, którą wiosenny, rzęsisty deszcz zalewa na kilka godzin" („,Kurier Warszawski" 1936a: 6; 1936b: 6) ${ }^{23}$.

Co zastanawiające, dziennikarze międzywojenni nie widzieli żadnej sprzeczności w wykorzystaniu bulwaru jako arterii spacerowo-wypoczynkowej i jednocześnie komunikacyjnej - wręcz przeciwnie, z przytoczonych fragmentów wynika, że takie połączenie wydawało im się logiczne i oczywiste ${ }^{24}$. Jeśli uwzględnimy ówczesne, nieporównywalnie mniejsze niż obecnie natężenie ruchu samochodowego, przestaje nas dziwić, że połączenie aspektów reprezentacyjnych, rekreacyjnych i komunikacyjnych bulwaru nadwiślańskiego nie budziło kontrowersji. Ciekawy artykuł na temat stopnia zmotoryzowania Polski, zatytułowany Cywilizacja, opublikowano w połowie lat 30. w tygodniku „Świat" (1935b: 7). Autor wspomnianego tekstu przytacza wyliczenia dotyczące liczby mieszkańców na 1 samochód w krajach Europy i świata. Polska zajmuje w zestawieniu 29 miejsce na 30 badanych państw (na czele są Stany Zjednoczone) z wynikiem aż 1275 osób na auto (ok. 24 tys. samochodów w całym kraju), wyprzedzając w Europie jedynie Albanię (w zestawieniu nie ujęto Irlandii i Bułgarii oraz „państw-liliputów"). Można założyć z niemal całkowitą pewnością, że liczba aut w Warszawie znacznie przewyższała średnią krajową, niemniej jednak natężenie ruchu pojazdów nad Wisłą musiało być wówczas wielokrotnie mniejsze niż obecnie i nie mogło, tak jak współcześnie, utrudniać dostępu do brzegów rzeki. Dla porządku należy także dodać, że jako arteria komunikacyjna miał służyć jedynie tzw. górny bulwar, co jest zrozumiałe i oczywiste, gdyż bulwar dolny znajdował się poniżej poziomu wałów przeciwpowodziowych i liczono się z jego czasowym zalewaniem w czasie wysokiego stanu wód ${ }^{25}$.

\footnotetext{
${ }^{23}$ „Wąską paszczą" nazwano w tym artykule wzmiankowany już przejazd pod torami kolei obwodowej na Żoliborzu na przedłużeniu dzisiejszej ul. Krajewskiego.

24 Współczesnego czytelnika może to razić i zaskakiwać, ponieważ obecnie trasa szybkiego ruchu, stanowiąca drogę tranzytową przez Warszawę, tzw. Wisłostrada, w powszechnym mniemaniu odpycha Warszawę od Wisły. Ze względu na zbyt duży ruch kołowy generowanie dokuczliwego hałasu oraz swoją szerokość i małą liczbę przejść dla pieszych trasa utrudnia dostęp nad brzegi rzeki (por. Wisłostrada 2015).

25 Sytuację, gdy bulwar dolny nad Wisłą znajdował się całkowicie pod wodą, mieliśmy choćby w czasie powodzi w 2010 r., gdy przy poziomie Wisły sięgającym $780 \mathrm{~cm}$ wszelkie urządzenia poniżej poziomu wałów zostały zalane.
} 
Wspominając o komunikacyjnej roli pobrzeża Wisły, warto zaznaczyć, że w prasie polskiej sama rzeka bywała postrzegana jako arteria komunikacyjna. Kilkukrotnie pojawiał się pomysł utworzenia w Warszawie tramwaju wodnego, łączącego brzegi Wisły i przybliżającego do siebie północne i południowe dzielnice miasta. Spełniałby on funkcję nie tylko turystyczno-krajoznawczą i rekreacyjną. W sytuacji, gdy stolica posiadała tylko cztery mosty (Kierbedzia, ks. Poniatowskiego, Średnicowy oraz Gdański), mógłby realnie wpłynąć na poprawę stanu komunikacji miejskiej. Trzeba pamiętać jednak, że pomysł ten pojawił się na łamach prasy stosunkowo późno - po raz pierwszy dopiero w roku 1935. Był on zapewne związany z planami urbanistycznymi Stefana Starzyńskiego, kierującego magistratem od 1934 r., który widział w bulwarach nadwiślańskich i tramwaju wodnym arterię komunikacyjną łączącą ogromne kompleksy miejskie, jakie miały powstać w ciągu kilkunastu lat. Mowa tu o dzielnicy reprezentacyjnej Marszałka Józefa Piłsudskiego, terenach wystawowych na Saskiej Kępie i parkach olimpijskich na Siekierkach i Kępie Potockiej²:

Wisła dotychczas nie jest arterią komunikacyjną, jaką być powinna (...) Już obecnie Wisła mogłaby być wykorzystywana do lokalnej komunikacji pasażerskiej, przy pomocy małych statków motorowych - tramwaju wodnego, obsługującego oba brzegi. Z uwagi na małą liczbę mostów oraz znaczną odległość niektórych pobrzeży od miejskich linii tramwajowych i autobusowych, komunikacja wiślana miałaby duże znaczenie i zapewnione powodzenie. Statki motorowe, kursujące normalnie między Siekierkami a Bielanami, mogłyby w dni świąteczne wydłużać swe kursy do Młocin i Wilanowa, umożliwiając piękne spacery. Komunikacja taka winna być jak najrychlej zorganizowana (Starzyński 1939: 6).

Nie bez znaczenia dla konieczności uporządkowania brzegów Wisły był aspekt bezpieczeństwa. Niejednokrotnie podkreślano, że nieuporządkowane brzegi rzeki to dobre miejsce dla przestępców i innych przedstawicieli półświatka. Nie znając statystyk policyjnych z okresu międzywojennego nie jesteśmy w stanie stwierdzić, czy rzeczywiście Powiśle i okolice rzeki charakteryzowały się wyższym wskaźnikiem przestępczości niż inne rejony miasta, nie ulega jednak wątpliwości, że poczucie bezpieczeństwa przypadkowego warszawiaka, który tam docierał, było bardzo niskie. O odepchnięciu stolicy od rzeki mówiono także $w$ tym kontekście, że nikt nie będzie przychodził nad Wisłę, dopóki będzie tam niebezpiecznie, a będzie tak, dopóty brzegi nie zostaną uporządkowane. Za przykład niech służy artykuł z„Polski Zbrojnej” (1934: 4), może nieco wyolbrzymiający i demonizujący zagrożenia na Wybrzeżu Gdańskim. Jego autor jednak niemal wprost pisze, że regulacja bulwarów przyniesie poprawę bezpieczeństwa nad brzegami rzeki:

Dla wielu pobrzeże Wisły jest synonimem dzikiego zachodu, gdzie z nastaniem zmroku króluje złodziej i opryszek. Wiemy, że rzeczywistość jest bardzo zbliżona do tej opinii. Na odcinku

${ }^{26}$ O planach urbanistycznych Starzyńskiego można przeczytać w jego licznych, wydanych drukiem przemówieniach, wywiadach prasowych czy choćby przedmowach do wystaw varsavianistycznych. Wiele z nich znajduje się w publikacji Archiwum Prezydenta Warszawy Stefana Starzyńskiego, red. M.M. Drozdowski (2004) 
od mostu Kierbedzia do Cytadeli, Wisła jest niedostępna. Jeżeli się ktoś tam zapuści, to często drogę powrotną obrać musi przez prosektorium na Bródno lub na Powązki, a jeszcze częściej nie może doliczyć się pieniędzy lub kosztowności. Odcinek między mostem Kierbedzia a mostem Poniatowskiego jest znośny, ale (...) wieczorem przylega do niego sława Powiśla z Antkami, majchrami i Czarnymi Mańkami ${ }^{27}$. (...) Czas najwyższy, aby [ich wszystkich przyp. K. P.] i z opinii, i z rzeczywistości usunąć.

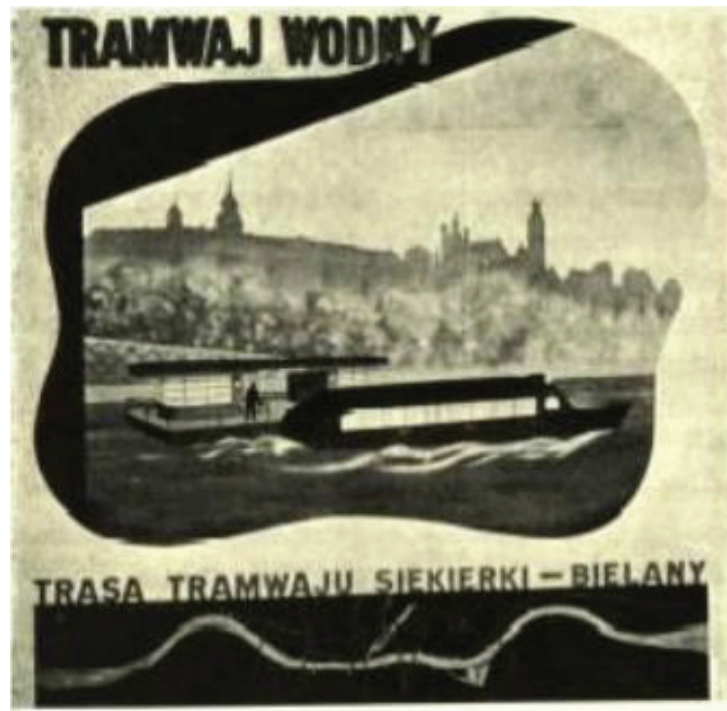

\section{1. Tramwaj wodny miał być uzupełnieniem nadwiślańskiej arterii komunikacyjnej (Warszawa przyszłości 1936: 57)}

Warto pochylić się także nad zasygnalizowanym dotychczas jedynie problemem terenów nadwiślańskich jako potencjalnie najbardziej reprezentacyjnej części miasta. Było to niezwykle często komentowane w prasie, w której wspominano, że bulwary podniosą prestiż miasta także w oczach przyjezdnych i upodobnią je do pięknych europejskich stolic: Berlina, Budapesztu, Paryża czy Wiednia. Można tu przytoczyć kilka podobnych w swojej wymowie fragmentów z "Kuriera Warszawskiego": „Warszawa wyciągnęła się długim pasem wzdłuż Wisły. Tym nieprzerwanym pasem ciągnąć się mogą bulwary nad Wisłą".,,Można je przybrać, w miejscach dostępnych, w cały aparat wielkomiejskich imprez rozrywkowych: ozdobić kwiatami, kawiarniami, restauracjami, barami, dansingami, kabaretami, teatrzykami, kinami”. „Wiele miejsc na wybrzeżach poświęcono już wychowaniu fizycznemu i sportowi. Wszystko to razem może wytworzyć swoisty charakter odcinków, znamienny już zresztą we wszystkich wielkich europejskich stolicach" (1929: 8; 1935: 16; 1936d: 6).

27 Czarna Mańka i Antek to postaci znane z tzw. legend miejskich Warszawy. Czarna Mańka była rzekomo znana przed wojną na Pradze i Powiślu luksusową prostytutką, a rzezimieszek i złodziej Antek jej jedyną prawdziwą miłością. Ich historia zakończyła się tragicznie. Obie postaci przeniknęły do kultury warszawskiej. W 2009 r. spektakl Czarna Mańka - Królowa Przedmieścia, zainspirowany ich historią, wystawił teatr Scena Lubelska 30/32 (por. Czarna Mańka 2009). 


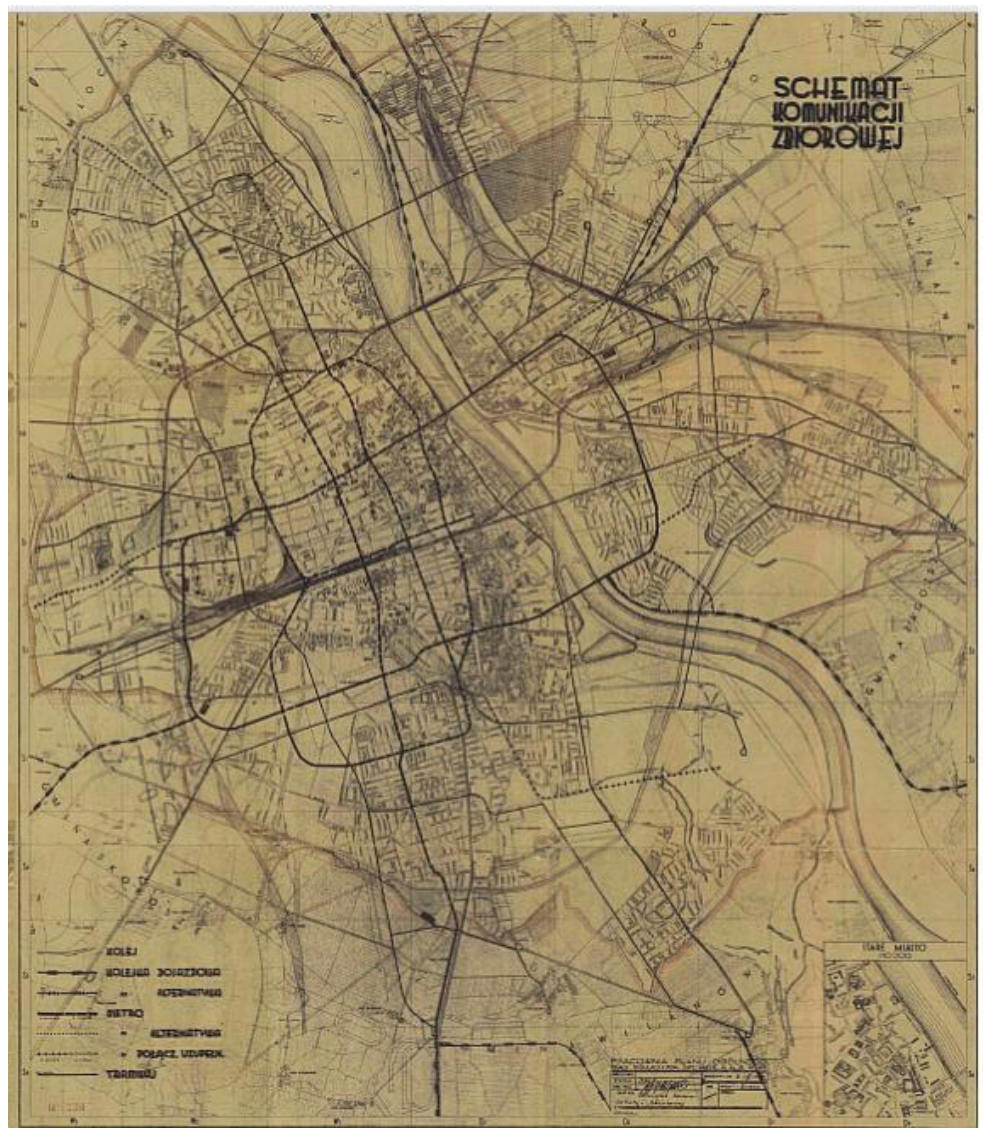

II. 2. Mapa - schemat warszawskiej komunikacji miejskiej z 1938 r. z naniesionymi planowanymi inwestycjami komunikacyjnymi, w tym siecią metra. Bulwar - arteria nadwiślańska miał ciągnąć się od projektowanego toru regatowego na Siekierkach (widocznego w łuku Wisły w południowej części miasta) aż do Bielan i dalej Młocin (rejon fortu widocznego na północnym krańcu mapy) (Plan metra 1938)

Na ten aspekt wybrzeża Wisły nie pozostawała obojętna także redakcja „Polski Zbrojnej" (1934:4):„Paryż, Berlin czy Wiedeń rzeki swe oprawiły w odpowiednie ramy, które mają ważny i praktyczny cel - zbliżyć mieszkańców do wody. $U$ nas jest zupełnie inaczej, taki stan jest nienormalny, jest wręcz absurdalny".

Chyba najbardziej wymowny jest jednak fragment artykułu, jaki ukazał się w „Rzeczpospolitej" (1930a: 8):

Każdy, kto był w Budapeszcie, pamięta na pewno aleje nad Dunajem i widok z nich na Budę, który zdaje się być fragmentem malarskiego arcydzieła. Wybrzeże w stolicy naddunajskiej jest najbardziej reprezentacyjną częścią miasta. (...) Tam znajdują się najwykwintniejsze restauracje i kawiarnie, tam zmęczony skwarem budapeszteńczyk znajdzie odpoczynek i wytchnienie. A u nas?. 


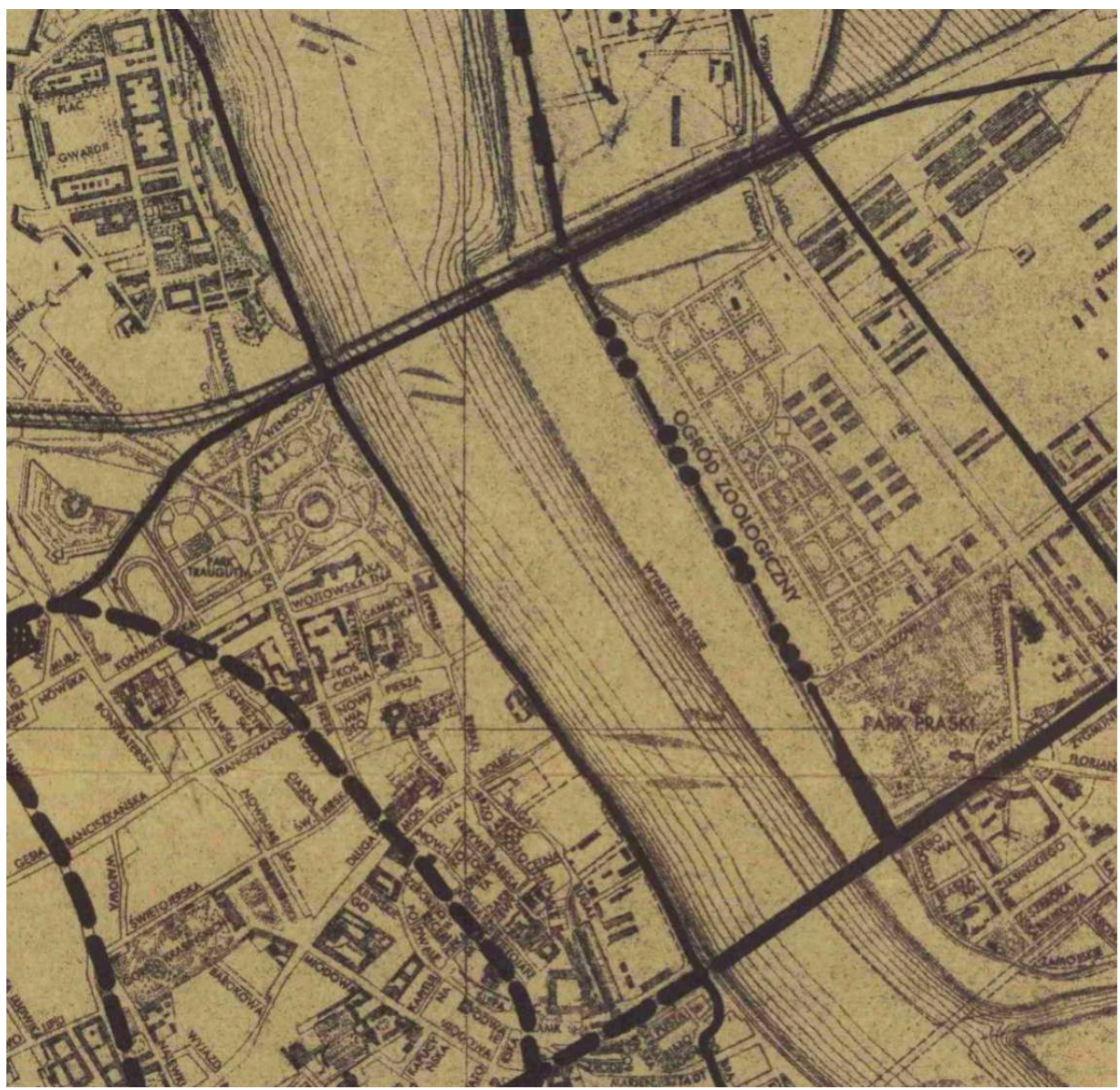

III. 3. Pobrzeże Wisły w środkowej części Warszawy, od Zamku Królewskiego i mostu

Kierbedzia do Cytadeli, 1938 r. W rejonie tym częściowo realizowano pod koniec lat 30. drugi (po odcinku most Poniatowskiego - most Kierbedzia) fragment reprezentacyjnego lewobrzeżnego bulwaru o długości ok. 1,5 km. Docelowo miał rozciągać się na kilkanaście kilometrów, od Siekierek (lub nawet Wilanowa) do Młocin (Plan metra 1938)

Kolejnym, być może najważniejszym aspektem budowy nadwiślańskiej promenady (ze względu na liczbę pojawiających się na ten temat głosów) była więc kwestia zrównania się Warszawy z miastami zachodnioeuropejskimi, nabrania prawdziwie europejskiego sznytu. Wątek ten będzie zajmował naczelne miejsce w prasie polskiej przez cały okres międzywojenny, co, jak się wydaje, świadczy o przekonaniu, że Polska jest pełnoprawnym, ważnym, europejskim krajem i nie powinna cywilizacyjnie w niczym ustępować reszcie Starego Kontynentu. Ambicją elit intelektualnych Warszawy i Polski, wyrażaną piórami piszących o Wiśle dziennikarzy, było nadanie miastu rangi równej opromienionym starym blaskiem stolicom europejskim. 
Nikt jednak nie łudził się, że dorównanie Europie Zachodniej dokona się szybko i łatwo. Obok wspominanych już problemów natury finansowej znacznym utrudnieniem było rozwiązanie sprawy dotychczasowego użytkowania brzegów Wisły, pobrzeże wiślane bowiem, jakkolwiek nieuregulowane i nieuporządkowane, nie było terenem pustym. W latach 20. zajmowały je tereny wielu klubów i przystani sportowych, zakładów piaskarskich, budynków gospodarczych pobliskich zakładów przemysłowych czy wreszcie Kolei Państwowej, która wybudowała w 1923 r. przecinający brzegi Wisły nasyp kolei średnicowej - infrastruktura ta bywała wprawdzie przedmiotem krytyki prasy, ale stanowiła w ówczesnych warunkach transportowych inwestycję niezbędną (por. Drozdowski 1991:316-317). Wszystkie istniejące zabudowania utrudniały racjonalne zagospodarowanie brzegów Wisły. Jakkolwiek w prasie nie odmawiano prawa do istnienia żadnej instytucji znajdującej się nad brzegami Wisły, to jednak wskazywano na potrzebę daleko idących ustępstw z ich strony z przeniesieniem siedzib włącznie. Wszystko to miało służyć celowi nadrzędnemu - budowie bulwarów na europejskim poziomie, a dzięki nim upiększeniu i unowocześnieniu miasta: „W historycznym rozwoju Warszawa rozwijała się w kierunku równoległym do rzeki; północno-południowym. W okresie zaboru ten naturalny rozwój miasta został wstrzymany. Budowa cytadeli, (...) dworca wiedeńskiego, fabryk, gazowni nadała nabrzeżu wiślanemu charakter przemysłowy. Powiśle stało się dzielnicą odgradzającą Wisłę od Warszawy” ("Gazeta Polska" 1936a: 10).

Problem ten opisywano nieraz w sposób bez mała poetycki: „Warszawa rozrasta się, rozpędza ku północy, zwycięsko odzyskuje historyczne szlaki swego rozwoju. Po latach rozłąki powraca stolica kraju ku rzece, stroi ją w nadbrzeżne bulwary, pasmami zieleni zdobi jej wody. W jej nurtach zmywa z siebie szpetotę - symbol długich lat niewoli" („Gazeta Polska" 1936b: 10).

Z satysfakcją i zadowoleniem przyjmowano informacje o likwidowaniu na pobrzeżu wiślanym kolejnych zabudowań i przygotowaniach do realizacji spójnego, jednolitego bulwaru o charakterze reprezentacyjnym. Trzeba w tym miejscu zauważyć, że działania magistratu były zgodne z postulatami prasowymi. Miasto realizowało projekt dostosowania, a w razie potrzeby również przeniesienia i usunięcia zabudowy licznych klubów i przystani sportowych. Tych ostatnich nad Wisłą nie brakowało w 1930 r. na wybrzeżu wiślanym funkcjonowały 24 przystanie sportowe, w tym 11 po stronie lewobrzeżnej, oraz przystanie prywatne, plaże i kąpieliska. Znaczna część klubów obok przystani miała także swoje budynki, najczęściej drewniane. Jakkolwiek nie można nie docenić roli tych stowarzyszeń w upowszechnianiu kultury fizycznej w Warszawie, grodząc swoje tereny, utrudniały one w wielu miejscach dostęp do Wisły osobom niezwiązanym z wioślarstwem, a już z pewnością nie ułatwiały racjonalnego zagospodarowania brzegów rzeki ${ }^{28}$. Celem stołecznych włodarzy było również stopniowe ograniczanie nieestetycznej zabudowy przemysłowej i likwidacja wszelkiego „bieda-budownictwa”, by w przyszłości stworzyć nad rzeką monumentalną

28 Liczby przytoczone za (Gawkowski 2007: 327, 337). 
promenadę. Potwierdza to w wywiadzie udzielonym tygodnikowi „Świat” W 1935 r. inż. Henryk Orleański²9:

Przede wszystkim chcemy jak najprędzej zeuropeizować wybrzeże kościuszkowskie. Powoli zaczynają znikać z wybrzeża kościuszkowskiego stare rudery - a ich miejsce zajmują nowoczesne kluby sportowe. W miarę też możliwości asfaltujemy bulwary. Asfalt otrzymał już bulwar od mostu Poniatowskiego do ul. Tamki (...), przewiduje się zaś wyasfaltowanie jak najśpieszniejsze aż do mostu Kierbedzia. Myślimy poważnie o usunięciu wszystkich klubów sportowych wyżej, tak, aby samym brzegiem rzeki puścić bulwar. Nawet WTW ${ }^{30}$ otrzymało zawiadomienie, że możliwym będzie wymówienie terenu pod bulwar. (...) Wszystkie kluby, znajdujące się na linii Wału Miedzeszyńskiego, otrzymają nakaz obniżenia swoich budynków tak, aby nie zakrywały sobą widoku na Wisłę. (...) Dla piaskarzy przewidzieliśmy nowe tereny w górze rzeki. Muszą oni powoli ustępować "cywilizacji Wisły” (1935c: 10-11).

Kilka lat później „Gazeta Polska” informowała, że miasto nadal prowadzi lub też stara się prowadzić politykę, o której mówił inż. Orleański³1:

Od kilku lat miasto prowadzi prace mające na celu uregulowanie wybrzeży. Prócz robót o charakterze inwestycyjnym, przeprowadzane są roboty o charakterze porządkowym. (...) Piaskarze zostali przeniesieni na Siekierki. (...) W toku znajduje się akcja likwidowania domków pływających - mieszkalnych. (...) Skasowana zostanie miejska plaża oraz kluby (Sokół, Klub Harcerski) znajdujące się między mostem Poniatowskiego, a linią średnicową. Kluby te będą pomieszczone na wybrzeżu miedzeszyńskim w pobliżu przecięcia z wałem gocławskim. Również tylko rok jeszcze pozostaną na dawnych miejscach kluby i przystanie między linią średnicową a portem handlowym na Pradze. W tym samym okresie zostaną zlikwidowane kluby i plaże na wybrzeżu Helskim. W ten sposób odsłonięty zostanie widok z brzegu praskiego na zabytkową część Warszawy - Zamek i Stare Miasto. (...) Po wykonaniu tych zamierzeń pozostanie jeszcze otwartą sprawa likwidacji klubów na lewym brzegu Wisły w obrębie Warszawy wzdłuż ul. Solec i przy ul. Wioślarskiej. Pozostanie również do uregulowania sprawa oficerskiego Yacht-Klubu, którego obecny budynek stanowi poważną przeszkodę w uregulowaniu nadbrzeżnych bulwarów. Są to jednak sprawy o tyle trudniejsze, że kluby mające swoje siedziby na warszawskim brzegu powznosiły budynki murowane. (...) Sądzić jednak można, że w ciągu lat najbliższych i ta sprawa będzie załatwiona („Gazeta Polska” 1939a: 3).

Niejedynym obiektem żalów i utyskiwań dziennikarzy, którzy życzyliby sobie szybszego uczynienia z brzegów Wisły reprezentacyjnej części miasta, było bezładne

29 Inż. H. Orleański pełnił za czasów rządów S. Starzyńskiego w magistracie funkcję naczelnika ds. regulacji Wisły.

30 Warszawskie Towarzystwo Wioślarskie było najstarszym towarzystwem sportowym założonym w Warszawie. Jego powstanie datuje się na rok 1878. Przed odzyskaniem niepodległości pełniło, oprócz funkcji sportowych, ważną rolę kulturalną i społeczną jako organizacja starająca się krzewić patriotyzm i umacniać polskość. Odegrało istotną rolę dla Warszawy w latach I wojny światowej, przewożąc jej mieszkańców przez Wisłę po zburzeniu mostów. Fakt, że nawet WTW musiało się liczyć z ustępstwami na rzecz bulwaru, świadczy o wielkiej determinacji magistratu w jego realizacji (por. Gawkowski 2007: 225-228).

31 Notabene była to w zasadzie jedyna gazeta, która w okresie 1937-1939 interesowała się bulwarami nadwiślańskimi, co jest o tyle dziwne, że w 1935 r. rozpoczęto z rozmachem drugi etap ich budowy- od mostu Kierbedzia do Cytadeli. 
zabudowanie wybrzeża. Bardzo wiele miejsca poświęcono niekorzystnej z punktu widzenia rozwoju Warszawy polityce zaborcy rosyjskiego, który niejako celowo zaniedbał regulację i uporządkowanie Wisły w mieście, czyniąc to ze względów strategicznych (Kieniewicz 1976: 181, 202-207), ale też ideologicznych. Rosjanom zależało na uczynieniu z Warszawy miasta dusznego, ciasnego, peryferyjnego, nieodbierającego splendoru centrom Imperium Romanowów. Przede wszystkim jednak miało ono być twierdzą - jedną z zespołu twierdz przywiślańskich, chroniących zachodnie rubieże Rosji (obok Modlina, Dęblina czy Brześcia nad Bugiem). Swobodny, samorzutny rozwój z pewnością ograniczyłyby jego walory obronne. W okresie tym względy wojskowe stały zresztą także na przeszkodzie choćby rozszerzaniu Warszawy o tereny podmiejskie, przez co miasto, $w$ którym przyrost ludności był bardzo dynamiczny ${ }_{\text {," }}$ dusiło się". Powiśle pozostawało rejonem nieuregulowanym, bardzo zaniedbanym, trzykrotnie (w latach 1868, 1884 i 1891) zalewanym aż do ul. Topiel i Browarnej. Władze rządowe dwukrotnie w II połowie XIX w. nie wydały zgody na budowę w Warszawie tzw. trzeciego mostu (most Poniatowskiego) - wzniesiono go dopiero w roku 1914. Zaniedbane brzegi Wisły doskonale wpisywały się w koncepcję prowincjonalnego miasta:

Rosjanie w zadziwiający wręcz sposób zaniedbywali dwa gmachy, w których bądź co bądź koncentrowała się siła rządząca - Zamek Królewski i Belweder. W jednym i drugim przypadku nie zrobili nic, aby miejsce oczyścić, ucywilizować, przybrać prawdziwie po wielkomiejsku (...). Nic dziwnego, że przy takim nastawieniu zaborcy nie myśleli również o uporządkowaniu wybrzeża przed Zamkiem. Ta Wisła, którą nasi zaborcy starannie zaniedbywali, nie pozwalając na estetyczne porządkowanie nabrzeży jakoby ze względów strategicznych dzisiaj staje się oczkiem w głowie Warszawy (Świat 1935a: 5)

Należy zauważyć, że brak zainteresowania i dbałości o wygląd brzegów rzeki w Warszawie w czasach zaboru rosyjskiego traktowany był jako dodatkowa przesłanka, mająca mobilizować do wytężonych prac w celu poprawy tego stanu rzeczy i likwidacji zaniedbań.

Nie można zapominać - choć dotychczas nie było to przedmiotem rozważań - że uporządkowanie brzegów Wisły nie miało dotyczyć jedynie jej części lewobrzeżnej. $\mathrm{Na}$ Pradze także miała powstać arteria nadbrzeżna o funkcjach podobnych do tej z przeciwległego brzegu. Bulwary praskie nie budziły tak wielkiego zainteresowania dziennikarzy, jak te po lewej stronie Warszawy i informacje o nich pojawiały się w gazetach rzadziej, tym niemniej kwestii praskiej nie można pominąć. Trasa komunikacyjna na Pradze, konkretnie na Wale Miedzeszyńskim, miała ułatwiać poruszanie się mieszkańcom stolicy i połączyć miasto z miejscowościami aglomeracji stołecznej aż do uzdrowiska w Otwocku. „Kurier Warszawski” informował: "Ważne roboty podjęto przy przebudowie Wału Miedzeszyńskiego. Posuwa się budowa drogi z chodnikami, prowadząca do cieszących się popularnością letnisk podwarszawskich. Autostrada zapewni miły widok na Wisłę" („Kurier Warszawski” 1936a: 6). 


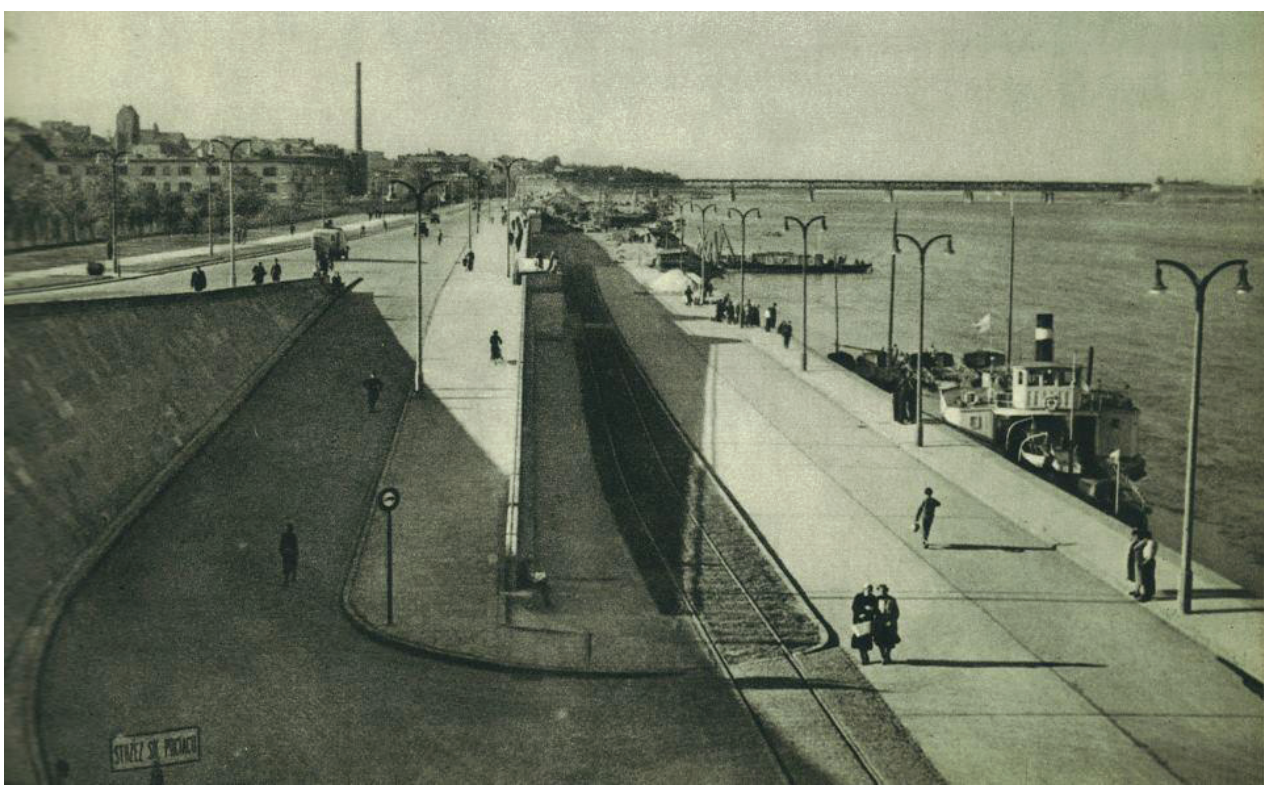

II. 4. Wybrzeże Gdańskie, reprezentacyjny bulwar nad Wisłą. Widok z okolic mostu Kierbedzia (wysokość Zamku Królewskiego) w kierunku północnym (ku Cytadeli) około roku 1937. W dalekiej perspektywie widać trwające nadal prace budowlane (Warszawski modernizm)

Tematem interesowali się również dziennikarze czasopisma „Świat”: „Drogę kołową do Otwocka postanowiono poprowadzić górą tak, aby z bulwaru roztaczał się piękny widok na Wisłę i Warszawę. Planuje się tu przeprowadzenie na wale drogi spacerowej, szerokości minimum 6 m, obok jezdni dalekobieżnej i wreszcie trzeciej jezdni dla ruchu lokalnego" („Świat" 1935c: 10).

Bulwar praski - co znajdowało odbicie także w prasie - miał stanowić cenne dopełnienie reprezentacyjnego brzegu Wisły po lewej stronie oraz harmonijnie łączyć się z planowanymi od połowy lat 30. terenami wystawowymi na Saskiej Kępie czy obszarami rekreacyjnymi jak Park Skaryszewski. Dla takiego wykorzystania Wisły na Pradze planowano nawet ograniczenie rozbudowy niedawno zbudowanego Portu Praskiego i przeniesienie części handlu rzecznego na tereny portu w podwarszawskiej wówczas miejscowości Żerań ${ }^{32}$. Notabene w okolice Żerania planowano też przenieść większość przystani wioślarskich, których magistrat nigdy nie planował likwidować (zapewne ze względu nie tylko na ich rolę w krzewieniu kultury fizycznej, ale też uwarunkowania prawne), a które, jak już zostało to przypomniane, nie ułatwiały uporządkowania

32 Port Praski budowano w latach 1919-1925. Jego lokalizację wybrano ze względu na to, że był to niezabudowany fragment terenu stosunkowo blisko centrum miasta. Ten wybór był jednak nierzadko krytykowany. W latach 30. planowano przenieść większą część handlu rzecznego do Żerania (obecnie w granicach Warszawy, w dzielnicy Białołęka). Budowę tego portu rozpoczęto w $1933 \mathrm{r}$. (Drozdowski 1991: 316-317). 
brzegów Wisły, o czym daje niedwuznacznie znać "Gazeta Warszawska”: „Port na Pradze ma być przeznaczony dla potrzeb stolicy, a port w Żeraniu tranzytowy. W pobliżu Żerania mają być ulokowane wszystkie przystanie sportowe. Z regulacją Wisły związana jest budowa kanału fabrycznego Żerań-Małkinia" („Gazeta Warszawska" 1935: 5).

Problem dostrzegano także w redakcji „Gazety Polskiej”:

Obecnie największą przeszkodą w racjonalnym zagospodarowaniu Wisły jest port. (...) Miejsce na port zostało źle wybrane. (...) Uniemożliwia nadanie nadbrzeżnej części dzielnicy charakteru monumentalnego (...) Budowy portu należałoby zaniechać (...) Trudno burzyć to, co już zostało zbudowane. Należy więc zostawić dwa wykończone baseny portowe, portu więcej nie rozbudowywać, a pozostałe tereny praskie poświęcić na utworzenie wielkiego parku pod przyszłą wystawę. Hasłem naszym winno być - frontem ku Wiśle, ale nie frontem ku portowi. Port wiślany w centrum miasta może tylko raz na zawsze odciąć miasto od

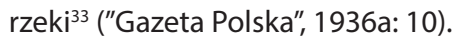

Warto dodać, że na praskim brzegu, położonym stosunkowo nisko, regulacja Wisły i zbudowanie bulwaru dodatkowo zwiększało bezpieczeństwo mieszkańców, praktycznie eliminując ryzyko powodzi, gazety zauważały jednak ten fakt nader rzadko ${ }^{34}$.

Podsumowując, problematyka regulacji urbanistycznej stolicy i zagospodarowania wybrzeża wiślanego jako jednego z jej najważniejszych elementów pojawiała się na łamach prasy ogólnopolskiej regularnie przez cały okres międzywojenny. Na podstawie lektury kilkudziesięciu artykułów można pokusić się o rekonstrukcję wizji bulwarów nadwiślańskich na łamach prasy, ponieważ w różnych latach i w gazetach o różnym profilu była ona zaskakująco podobna. Bulwary wyobrażano sobie jako potencjalną wizytówkę miasta, a po przeprowadzeniu regulacji Wisły i uporządkowaniu wybrzeża miały to być najbardziej reprezentacyjne tereny Warszawy, bogate w kawiarnie, restauracje, z dużą ilością zieleni, godne stolicy wielkiego państwa. Podkreślano przy tym, że w wielu stolicach europejskich tereny nadrzeczne są chlubą i dumą, a Warszawa jako centrum nowego, ale silnego kraju nie powinna im ustępować. Nie pomijano znaczenia praktycznego bulwarów dla stolicy - kładziono nacisk na ich rolę w połączeniu dzielnic północnych (głównie Żoliborza) oraz - na prawym brzegu - osiedli od Pragi aż do Otwocka wraz ze Śródmieściem, a także zmniejszenie natężenia ruchu w centrum miasta. Widziano w nich także zieloną arterię rekreacyjno-spacerową, której stolicy tak brakowało. Estetyczna rola bulwarów, upiększenie miasta poprzez odsłonięcie panoramy Zamku Królewskiego, również nie była bez znaczenia.

33 Przytoczone fragmenty są częścią referatu inż. J. Nagórskiego i głosu w dyskusji, jaki zabrał prezydent miasta S. Starzyński na zebraniu Związku Stowarzyszenia Przyjaciół Wielkiej Warszawy. Odbyło się ono na początku lutego 1936 r. w lokalu Klubu Społeczno-Politycznego (ul. Czackiego 12).

${ }_{34}$ Jedyną wzmiankę na temat „przeciwpowodziowej” roli bulwaru praskiego znajdujemy w "Kurierze Warszawskim” (1936b: 6). Znajduje się tam następujący passus: „Nie można mówić o regulacji wybrzeży, póki koryto rzeki nie zostanie uregulowane. (...) Na razie Wisła kaprysi, zmienia nurt, grozi powodzią, naraża na niebezpieczeństwo niskie brzegi prawej strony. (...) Bezpieczeństwo brzegów stanowi konieczność, bez której trudno podjąć hasło «frontem ku Wiśle», spopularyzowane i oklepane jak piękna aria katarynek". 
Powstanie bulwarów uważano za absolutnie konieczne, mimo wielkiej kosztowności takiego projektu. Rozumiano, że dobro miasta jest ważniejsze od partykularnych interesów nadrzecznych instytucji, od których wymagano ustępstw przy realizacji bulwarów. W projektach nie pomijano strony praskiej, do której regulacji i uporządkowania przywiązywano także dużą wagę. Z satysfakcją przyjmowano informacje o realizacji kolejnych etapów inwestycji. Widziano w niej historyczne, powtórne przesunięcie miasta „frontem ku Wiśle", a więc usunięcie jednej z przykrych pamiątek czasów zaborów.

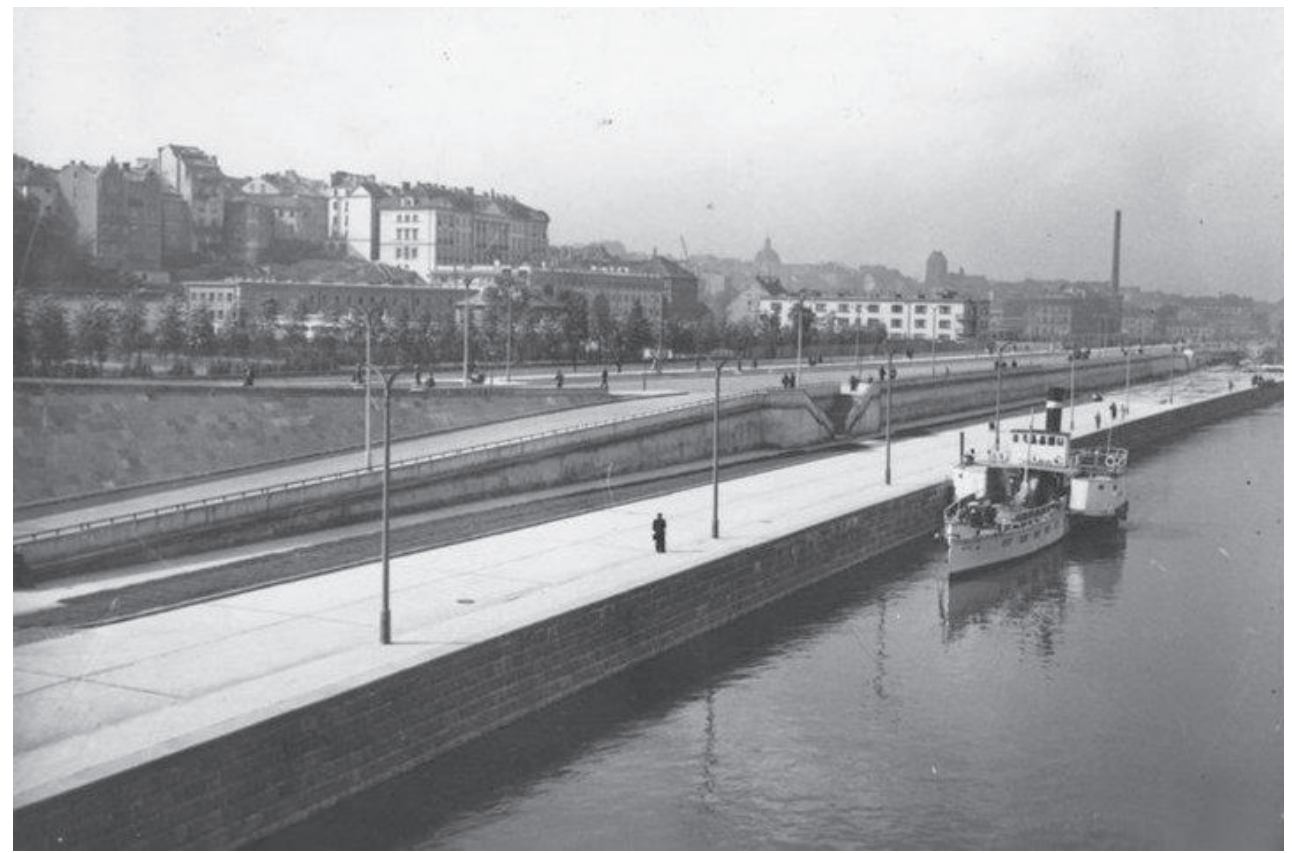

II. 5. Wybrzeże Gdańskie, lato 1938. Jedyny w pełni ukończony, prawdziwie reprezentacyjny odcinek wielkich bulwarów (Warszawski modernizm)

Niemal w pigułce wszystkie problemy poruszane w dwudziestoleciu międzywojennym podsumowuje artykuł, który ukazał się w "Gazecie Polskiej" kilkanaście dni przed agresją hitlerowskich Niemiec na II Rzeczpospolitą:

Wisła dotychczas nie jest arterią komunikacyjną, jaką być powinna (...) Wisła posiada dla stolicy kapitalną jakość, jako czynnik urbanistyczno-dekoracyjny (...) przez wiele dziesiątków lat niewykorzystywany. Stolica uciekała od Wisły. Jej wybrzeża stały się łupem ruder, fabryczek. (...) ulokowały się piaskarnie, przystanie wioślarskie, często w postaci ohydnych bud, prawem kaduka opanowały szmaty brzegów wiślanych (...) dopiero z objęcia prezydentury miasta przez p. St. Starzyńskiego Wisła przestaje być zapomnianym Kopciuszkiem. Kapitalnym dziełem jest stworzenie wielkiej, nowej arterii komunikacyjnej na Żoliborz (...) Zamek Królewski i Stara Warszawa otrzymują wspaniałą oprawę, dzięki budowie nowoczesnych bulwarów (...) Nie mniej ważne roboty przeprowadzono na prawym brzegu Wisły. 
Została uporządkowana i wyasfaltowana ważna arteria wylotowa - Wał Miedzeszyński. (...) Jeśli tak pięknie rozpoczęta praca nad urządzeniem wybrzeży Wisły nie napotka na nieprzewidziane trudności natury finansowej, to za kilkanaście lat staną się one pierwszorzędną ozdobą stolicy ${ }^{35}$.

Wybuch wojny i rychła klęska Polski przekreśliła nadzieję na zrealizowanie nadbrzeżnej arterii na miarę największych stolic europejskich. Pobrzeże Wisły zostało zagospodarowane w czasach powojennych, nie tętni jednak życiem. Lokalna w założeniu arteria komunikacyjna nad rzeką przerodziła się w Wisłostradę, ogromną trasę, która od wielu dziesięcioleci odpycha od niej miasto. Należy mieć nadzieję, że kiedy zostanie wreszcie ukończona rozpoczęta w styczniu 2013 r. ponowna przebudowa warszawskich bulwarów wiślanych, stanie się spełnieniem testamentu przedwojennych włodarzy miasta i intelektualistów piszących o Warszawie - mieście „frontem ku Wiśle"

\section{Literatura}

Durko J. (red.),1977, Bibliografia Warszawy. Wydawnictwa ciągłe 1919-1928, Wrocław-Gdańsk: Zakład Narodowy im. Ossolińskich.

Durko J. (red.), 1984, Bibliografia Warszawy. Wydawnictwa ciągłe 1929-1944, Wrocław-Gdańsk: Zakład Narodowy im. Ossolińskich.

Borecka E., Drozdowski M.M, Jaworska H. (red.), 1968, Warszawa II Rzeczpospolitej: 1918-1939, t. 1, Warszawa: PWN.

Borecka E., Drozdowski M. M., Jaworska H. (red.), 1970, Warszawa II Rzeczpospolitej: 1918-1939, t. 2, Warszawa: PWN.

Borecka E., Drozdowski M. M., Jaworska H. (red.), 1971, Warszawa II Rzeczpospolitej: 1918-1939, t. 3, Warszawa: PWN.

Borecka E., Drozdowski M. M., Jaworska H. (red.), 1972, Warszawa II Rzeczpospolitej: 1918-1939, t. 4, Warszawa: PWN.

Borecka E., Drozdowski M. M., Jaworska H. (red.), 1973, Warszawa II Rzeczpospolitej: 1918-1939, t. 5, Warszawa: PWN.

Bulwary Wiślane, http://wawalove.pl/Szukaj/bulwary+wi\%C5\%9Blane/ [dostęp 30.06.2015].

35 "Zagadnienie Wisły na obszarze Warszawy” („Gazeta Polska” 1939b: 6). Wielki entuzjazm „Gazety Polskiej" wobec planów inwestycyjnych S. Starzyńskiego i ogólnie pozytywną ocenę tego urzędnika tłumaczy zapewne w dużym stopniu fakt jego przynależności do tego samego obozu politycznego, co redaktorzy Gazety. Nawiasem mówiąc zastanawiające jest, dlaczego jedynie to czasopismo interesowało się sprawą bulwarów nadwiślańskich po 1937 r. Sprawa ta warta byłaby zbadania. ${ }^{36}$ Pierwszy odcinek nowych bulwarów (część między ul. Boleść a mostem Śląsko-Dąbrowskim), został oddany do użytku z niemal rocznym opóźnieniem. Prace na całym pobrzeżu wiślanym, sukcesywnie opóźniane przez warunki hydrologiczne i pogodowe oraz wysokie stany rzeki, dodatkowo znacznie skomplikował fakt, że na przełomie stycznia i lutego 2015 r., bankructwo ogłosiła firma będąca głównym wykonawcą całego przedsięwzięcia - Hydrobudowa Gdańsk. Inwestycji groziła utrata środków z Unii Europejskiej. Od lipca 2015 r. warszawiacy mogą jednak cieszyć się centralnym odcinkiem nadwiślańskiej arterii spacerowej. Docelowo odnowiony bulwar ma rozpościerać się nad Wisłą od Cytadeli aż do Portu Czerniakowskiego. Mają się przy nim znajdować: wodny park zabaw, plaża miejska, amfiteatr, ogrody dydaktyczne oraz siedem pawilonów, w których znajdą się m.in. galerie i kawiarnie. O szczegółach przebiegu inwestycji można przeczytać $m$. in. na stronie internetowej (Bulwary Wiślane). 
Canaletto 1770, Widok Warszawy od strony Pragi, (w:) Canaletto. Malarz Warszawy, oprac. M. Wallis, Warszawa: Wydawnictwa Artystyczne i Filmowe Auriga.

Canaletto 1774, Widok Warszawy od Pałacu Ostrogskich do Zamku Królewskiego, (w:) Canaletto. Malarz Warszawy, oprac. M. Wallis, Warszawa: Wydawnictwa Artystyczne i Filmowe Auriga.

Czarna Mańka - Królowa Przedmieścia, (2009), www.mmwarszawa.pl [dostęp 9.08. 2010].

Drozdowski M.M., 1991, Warszawa w latach 1914-1939, t. 4, Warszawa: PWN.

Drozdowski M.M., Zahorski A., 2004, Historia Warszawy, Warszawa: Jeden Świat.

„Dziennik Zarządu Miejskiego m. st. Warszawy", 1920, [brak autora i tytułu], nr 22, 6.03.1920.

Gawkowski R. 2007, Encyklopedia klubów sportowych międzywojennej Warszawy ijej najbliższych okolic w latach 1918-39, Warszawa: Wydawnictwo Uniwersytetu Warszawskiego.

"Gazeta Polska", 1936a, [brak autora i tytułu], nr 39, 8.02.1936 r.

„Gazeta Polska", 1936b, [brak autora i tytułu], nr 234, 22.08.1936 r.

"Gazeta Polska”, 1939a, [brak autora i tytułu], Wywiad z inż. Henrykiem Orleańskim, nr 81, 22.03.1939 r.

„Gazeta Polska”, 1939b, [brak autora], Zagadnienie Wisły dotychczas obszarze Warszawy, nr 218, 7.08. $1939 \mathrm{r}$.

"Gazeta Warszawska", 1925, [brak autora i tytułu], nr 239, 1.09.1925 r.

"Gazeta Warszawska", 1928, [brak autora i tytułu], nr 291, 1.10.1928 r.

„Gazeta Warszawska”, 1935, [brak autora i tytułu], nr 131, 10.05.1930 r.

Gniewiński C, 1939, Inwestycje m. st. Warszawy w dziale dróg i mostów. Ulice, bulwary, melioracje wodne, Warszawa: [brak wydawcy].

Herbst S. i in. (red.), 1975, Encyklopedia Warszawy, Warszawa: PWN.

Kaczyński L., (2004), Przedmowa (w:) Archiwum Prezydenta Warszawy Stefana Starzyńskiego, red. M.M. Drozdowski, Warszawa: Oficyna Wydawnicza Rytm.

Kieniewicz S. (red.), 1976, Warszawa w latach 1795-1914, t. 3, Warszawa: PWN.

Klein F., Rudnicki C, 1928, Regulacja i zabudowa miasta Warszawy: [brak wydawcy].

Paczkowski A., 1980, Prasa polska w latach 1918-1939, Warszawa: PWN.

„Kurier Warszawski”, 1928, [brak autora i tytułu], nr 320, wyd. poranne, 13.11.1928 r.

„Kurier Warszawski", 1929, [brak autora i tytułu], nr 16, wyd. poranne, 16.01.1929 r.

„Kurier Warszawski”, 1930, [brak autora i tytułu], nr 216, wyd. wieczorne, 9.08.1930 r.

„Kurier Warszawski”, 1931, [brak autora i tytułu], nr 217, wyd. wieczorne, 10.08.1931,

„Kurier Warszawski”, 1932, [brak autora], Wisła i wybrzeża, nr 144, 26.05.1932 r.

„Kurier Warszawski”, 1933, [brak autora i tytułu], nr 15, wyd. wieczorne, 15.01.1933 r.

„Kurier Warszawski", 1935, [brak autora i tytułu], nr 163, wyd. wieczorne, 16.06.1935 r.

„Kurier Warszawski”, 1936a, [brak autora i tytułu], nr 141, wyd. poranne, 20.05.1936 r.

„Kurier Warszawski”, 1936b, [brak autora i tytułu], nr 141, wyd. wieczorne, 21.05.1936 r.

„Kurier Warszawski”, 1936c, [brak autora i tytułu], nr 198, wyd. poranne, 21.07.1936 r.

„Kurier Warszawski", 1936d, [brak autora i tytułu], nr 198, wyd. wieczorne, 21.07.1936 r.

Pawłowski T., Zieliński J., 2008, Żoliborz - Przewodnik Historyczny, Warszawa: Rosner \& Wspólnicy.

Plan metra, 1938, Projekt sieci komunikacji szynowej po wprowadzeniu docelowego układu linii metra wg. projektu z 1938 roku, http://www.trasbus.com/plan1938-metro.htm [dostęp: 26.04.2016].

„Polska Zbrojna”, 1928 [brak autora i tytułu], nr 338, 5.12.1928 r. 
„Polska Zbrojna”, 1934, [brak autora i tytułu], nr 135, 15.05.1934 r.

„Rzeczpospolita”, 1930a, [brak autora i tytułu], nr 184, 8.07.1930 r.

„Rzeczpospolita”, 1930b, [brak autora], Nasze bulwary. Bolączki Warszawy, nr 184, 8.07.1930 r.

„Robotnik" 1925, [brak autora i tytułu], nr 238, 31.08.1925 r.

Szwankowski E., 1952, Warszawa - architektura i urbanistyka, Warszawa: Państwowe Wydawnictwa Techniczne.

Starzyński S., 1938, Potrzeby Warszawy, Warszawa: Miejskie Zakłady Graficzne.

Starzyński S., 1939, [brak tytułu], „Gazeta Polska”, nr 218, 7.08.1939 r.

„Świat" 1935a, [brak autora i tytułu], nr 30 z dn. 27.07.1935 r.

„Świat" 1935b, [brak autora], Cywilizacja, nr 30, 27.07.1935 r.

"Świat" 1935c, [brak autora i tytułu], Wywiad z inż. Henrykiem Orleańskim, nr 30, 27.07.1935 r.

Warszawa Przyszłości. Katalog wystawy w Muzeum Narodowym w Warszawie w dn. 28.03-3.05.1936r., 1936, przedm. S. Starzyński, Warszawa: Komitet Wystawy „Warszawa Przyszłości”.

Warszawski modernizm. Wybrzeże Gdańskie, około roku 1937, https://web.facebook.com/warszawskimodernizm/photos [dostęp 26.04.2016].

Warszawski modernizm. Wybrzeże Gdańskie, lato 1938, https://web.facebook.com/warszawskimodernizm/photos [dostęp 26.04.2016].

Wisłostrada, 2015, http://pl.wikipedia.org/wiki/Wisłostrada [dostęp: 28.07.2015].

Wolmar A., 1925, Od mostu Kierbedzia do mostu kolejowego, ,"Kurier Warszawski”, nr 74, wyd. poranne, 15.03.1925 r.

Zahorski A. (red.), 1984, Historia Warszawy w latach 1526-1795, Warszawa: PWN.

Żeromski S., 1925, [brak tytułu], ,"Kronika Warszawy”, 10.04 .1925 r. 